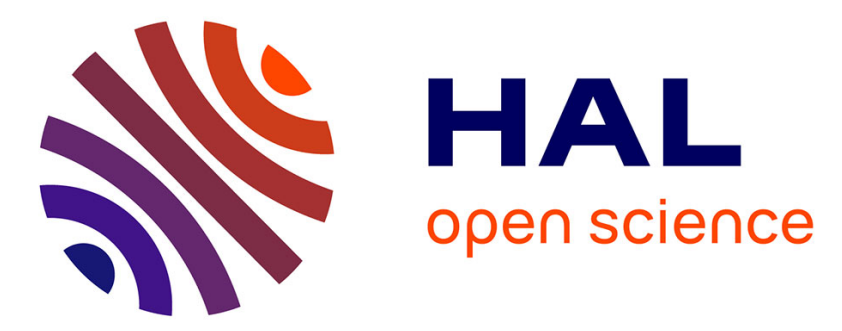

\title{
Organic nitrogen chemistry during low-grade metamorphism
}

\author{
Jean-Paul Boudou, Arndt Schimmelmann, Magali Ader, Maria Mastalerz, \\ Mathieu Sebilo, Léon Gengembre
}

\section{> To cite this version:}

Jean-Paul Boudou, Arndt Schimmelmann, Magali Ader, Maria Mastalerz, Mathieu Sebilo, et al.. Organic nitrogen chemistry during low-grade metamorphism. Geochimica et Cosmochimica Acta, 2008, 72 (4), pp.1199-1221. 10.1016/j.gca.2007.12.004 . bioemco-00256217

\section{HAL Id: bioemco-00256217 https://hal-bioemco.ccsd.cnrs.fr/bioemco-00256217}

Submitted on 27 Feb 2008

HAL is a multi-disciplinary open access archive for the deposit and dissemination of scientific research documents, whether they are published or not. The documents may come from teaching and research institutions in France or abroad, or from public or private research centers.
L'archive ouverte pluridisciplinaire HAL, est destinée au dépôt et à la diffusion de documents scientifiques de niveau recherche, publiés ou non, émanant des établissements d'enseignement et de recherche français ou étrangers, des laboratoires publics ou privés. 


\title{
Organic nitrogen chemistry during low-grade metamorphism
}

\author{
Jean-Paul Boudou ${ }^{\mathbf{a} *}$, Arndt Schimmelmann ${ }^{\mathbf{b}}$, Magali Ader ${ }^{\mathbf{c}}$, \\ Maria Mastalerz ${ }^{\mathbf{d}}$, Mathieu Sebilo ${ }^{\mathbf{a}}$, Léon Gengembre ${ }^{\mathbf{e}}$ \\ ${ }^{a}$ Université Pierre et Marie Curie, Paris 6, CNRS-UMR 7618, Case 120, Laboratoire de Biogéochimie et Ecologie des \\ Milieux Continentaux, 4, Place Jussieu, 75252 Paris Cedex 05, France \\ ${ }^{\boldsymbol{b}}$ Department of Geological Sciences, Indiana University, 1001 East Tenth Street, Bloomington, IN 47405-1405, U.S.A. \\ ${ }^{c}$ Institut de Physique du Globe de Paris Paris et Université Paris 7, CNRS-UMR 7154, Equipe de physico-chimie des fluides \\ géologiques, 2 Place Jussieu, 75251 Paris Cedex 05, France \\ ${ }^{d}$ Indiana Geological Survey, Indiana University, 611 N. Walnut Grove, Bloomington, IN 47405-2208, U.S.A. \\ ${ }^{e}$ Université des Sciences et Technologies de Lille, CNRS UMR 8181, Unité de Catalyse et Chimie du Solide, Bâtiment C3, \\ 59655 Villeneuve d'Ascq Cedex, France \\ *Corresponding author. Phone: +331470931 34,Fax: +33144274164,E-mail address: boudou@ccr.jussieu.fr
}

\begin{abstract}
Most of the organic nitrogen $\left(\mathrm{N}_{\mathrm{org}}\right)$ on Earth is disseminated in crustal sediments and rocks in the form of fossil nitrogen-containing organic matter. The chemical speciation of fossil $\mathrm{N}_{\text {org }}$ within the overall molecular structure of organic matter changes with time and heating during burial. Progressive thermal evolution of organic matter involves phases of enhanced elimination of $\mathrm{N}_{\text {org }}$ and ultimately produces graphite containing only traces of nitrogen. Long-term chemical and thermal instability makes the chemical speciation of $\mathrm{N}_{\text {org }}$ a valuable tracer to constrain the history of sub-surface metamorphism and to shed light on the subsurface biogeochemical nitrogen cycle and its participating organic and inorganic nitrogen pools. This study documents the evolutionary path of $\mathrm{N}_{\text {org }}$ speciation, transformation and elimination before and during metamorphism and advocates the use of XRay Photoelectron Spectroscopy (XPS) to monitor changes in $\mathrm{N}_{\text {org }}$ speciation as a diagnostic tool for organic metamorphism. Our multidisciplinary evidence from XPS, stable isotopes, traditional quantitative coal analyses, and other analytical approaches shows that at the metamorphic onset $\mathrm{N}_{\text {org }}$ is dominantly present as pyrrolic and pyridinic nitrogen. The relative abundance of nitrogen substituting for carbon in condensed, partially aromatic systems (where $\mathrm{N}$ is covalently bonded to three $\mathrm{C}$ atoms) increases exponentially with increasing metamorphic grade, at the expense of pyridinic and pyrrolic nitrogen. At the same time, much $\mathrm{N}_{\text {org }}$ is eliminated without significant nitrogen isotope fractionation. The apparent absence of Rayleigh-type nitrogen isotopic fractionation suggests that direct thermal loss of nitrogen from an organic matrix does not serve as a major pathway for $\mathrm{N}_{\text {org }}$ elimination. Instead, we propose that hot $\mathrm{H}$, O-containing fluids or some of their components gradually penetrate into the carbonaceous matrix and eliminate $\mathrm{N}_{\text {org }}$ along a progressing reaction front, without causing nitrogen isotope fractionation in the residual $\mathrm{N}_{\text {org }}$ in the unreacted core of the carbonaceous matrix. Before the reaction front can reach the core, an increasing part of core $\mathrm{N}_{\text {org }}$ chemically stabilizes in the form of nitrogen atoms substituting for carbon in condensed, partially aromatic systems forming graphite-like structural domains with delocalized $\pi$ electron systems (nitrogen atoms substituting for "graphitic" carbon in natural metamorphic organic matter). Thus, this nitrogen species with a conservative isotopic composition is the dominant form of residual nitrogen at higher metamorphic grade.
\end{abstract}

\section{INTRODUCTION}

Earth's geochemical nitrogen cycle links the relatively small pool of organic nitrogen in living biomass with a far more abundant inventory of fossil organic nitrogen and an even larger pool of inorganic nitrogen (Berner, 2006; and refs. therein), the latter being predominantly in the form of ammonium in minerals. Diagenesis and thermal maturation transform nitrogen-rich biomass into carbonaceous material where, in spite of its lowered abundance, organic nitrogen $\left(\mathrm{N}_{\text {org }}\right)$ continues to express a diverse and diagnostic geochemical 
character in terms of its chemical bonding to carbon. Progressive condensation and aromatization of sedimentary organic matter during burial, thermal maturation, and subsequent metamorphism (Fig. 1) produce an insoluble macromolecular carbonaceous matrix. This study investigates changes in $\mathrm{N}_{\text {org }}$ in anthracite and semi-graphite to constrain the behavior of nitrogen through geological cycles, and to strengthen $\mathrm{N}_{\text {org }}$ 's utility as a tracer during metamorphism (e.g., Pinti et al., 2001; van Zuilen et al., 2005; Pitcairn et al., 2005; Ader et al., 2006; Jia, 2006).

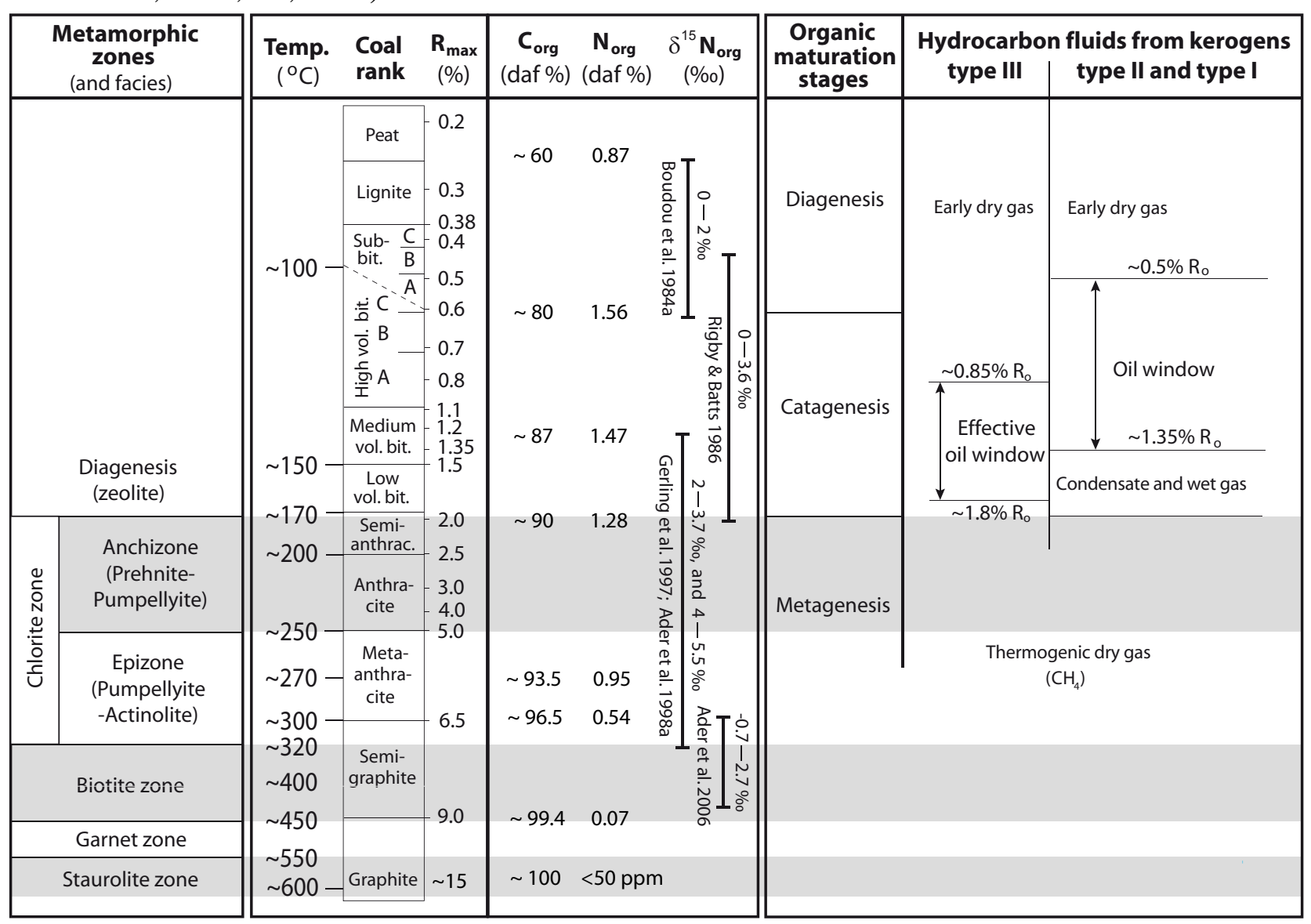

Fig. 1. Correlative overview on kerogen maturation stages, coal ranks (adopting US nomenclature), graphite and transitional phases, selected geochemical parameters, and fluid hydrocarbon generation. $\mathrm{N}_{\text {org }}$ concentrations and the isotopic range of observed $\delta^{15} \mathrm{~N}_{\text {org }}$ data refer to coal samples utilized in the cited studies and are not globally representative. $\mathrm{N}$ concentrations in graphite are from Ader et al. (2006) and van Zuilen et al. (2005). Correlations between temperature and individual parameters are approximate and may vary depending on local temperature and pressure conditions (Gretener and Curtis, 1982; Nickelsen, 1983; Paxton, 1983; Frey, 1986; Juster et al., 1987; Daniels, 1992; Daniels and Altaner, 1990; Daniels et al., 1990; Barker et al., 1998; Frey and Robinson, 1999; Mullis et al., 2003; Hower and Gayer, 2002; Petersen, 2006; Kwiecińska and Petersen, 2004; Schimmelmann et al., 2006; Wang et al., 2007).

It is difficult to avoid analytical artifacts when analyzing trace amounts of $\mathrm{N}_{\text {org }}$ in metamorphic carbonaceous matter using methods that rely on solvent extracts or pyrolyzates (e.g., Simoneit et al., 1971; Schmitter et al., 1983; Bennett et al., 2002). Non-destructive XRay Photoelectron Spectroscopy (XPS) presently offers the best approach to monitor maturity-related changes in the chemical character of $\mathrm{N}_{\text {org. }}$. XPS is based on the assessment of orbital ionization potentials by measuring the energy spectrum of electrons ejected from nitrogen atoms following bombardment with monoenergetic rays or particles. The electrostatic interactions between valence and core electrons are expressed as chemical shifts that are dependent on the chemical-structural environment of atoms. In the case of nitrogen, 
the XPS response follows the loss of an energetic electron from the $\mathrm{K}$ shell; hence the term N 1s XPS is used. Burchill and Welch (1989) used N 1s XPS in a pioneering study to elucidate chemical nitrogen characteristics in three anthracite samples. More recently, natural changes in the chemistry of nitrogen in a sequence from peat to low-volatile bituminous coal have been detected by N 1s XPS (Kelemen et al., 1994, 2006; Straka et al., 2000).

Experimental pyrolysis combined with XPS for type I, type II, and type III (coal) kerogens yielded similar observations regardless of the type of kerogen. Our data agree with Kelemen et al.'s $(1998,1999)$ observation of a strong relative increase of quaternary nitrogen with increasing maturity. Following extensive high-temperature pyrolysis of nitrogencontaining amorphous carbon precursors in the laboratory, essentially all edge-located nitrogen atoms (Fig. 2) are eliminated and remaining nitrogen atoms are preferentially located in the interior of the carbon lattice as thermally stable quaternary nitrogen (Isaacs, 1970; Pels et al., 1995; Stanczyk et al., 1995; Xiao et al., 2005). These trends have not been observed in nature where fluids, temperature, pressure, time and catalysts play important roles in the transformation of carbonaceous matter during metamorphism (e.g., Price and Dewitt, 2001; Schwab et al., 2005; Guedes et al., 2005). It is expected that during metamorphism $\mathrm{N}_{\text {org }}$ becomes increasingly integrated into sub-nanometric to nanometric sheets of adjoining ring structures (Fig. 2) that occur in isolation or are stacked to form basic structural units (Bustin et al., 1995). The anthracite basic structural unit consists of planar graphitoidal layers with an average C-C bond length of $0.143 \mathrm{~nm}$ (Bratek et al., 2002). The number of aromatic rings constituting a basic unit increases with rank. The predominant basic structural unit in anthracitic coals has a diameter of $0.75 \mathrm{~nm}$ across 3 condensed aromatic rings, whereas the basic unit of meta-anthracite measures $1.2 \mathrm{~nm}$ across 5 aromatic rings. During subsequent graphitization, the resulting polyaromatic sheets increase in size and may accommodate nitrogen atoms.

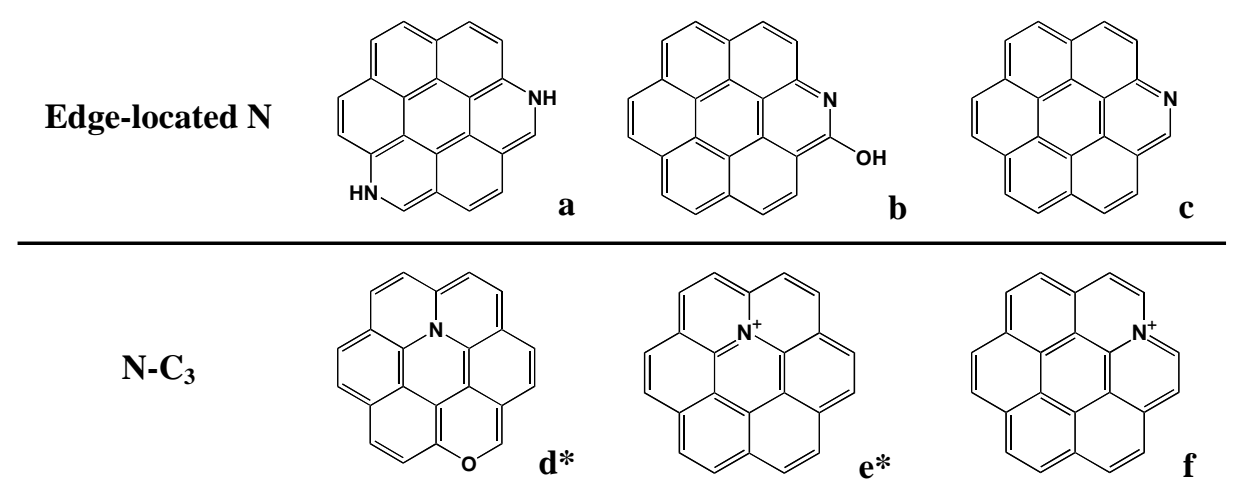

Fig. 2. Schematic nitrogen-containing molecular structures in condensed ring systems similar to coronene, where nitrogen substitutes for carbon and is either located along the edge and bonded to two carbon atoms (a, b, c), or is bonded to three carbon atoms and is termed $\mathrm{N}-\mathrm{C}_{3}$ nitrogen $(\mathbf{d}, \mathbf{e}, \mathbf{f})$. (a) Pyrrolic nitrogen; this type of nitrogen is frequently associated with a five-member cycle (e.g., pyrrole) that is not shown here. (b) Pyridonic nitrogen. (c) Pyridinic nitrogen. (d) Cyclazine-type nitrogen common to three fused rings. The oxygen atom in the ring system can be replaced by other heteroatoms (e.g., nitrogen, sulfur), a pyrrolic group, $\mathrm{CH}_{2}$, etc. (e) Quaternized cyclazine-type nitrogen or centrally-positioned quaternary nitrogen. (f) Quaternary nitrogen common to two fused rings. (*) Other types of cyclazine structures were presented by Boutique et al. (1984), Leaver (1986) and Pels et al. (1995).

Numerous studies on the structure and chemical composition of artificially produced nitrogen-doped graphitic materials document the occurrence of covalently bonded nitrogen atoms substituting for carbon atoms in condensed, partially aromatic systems. In these systems, only few nitrogen atoms will be linked to another nitrogen atom because the much larger C-N binding energy renders N-N single bonds thermodynamically unstable in the 
presence of excess carbon (Ripalda et al., 1998). Instead, most nitrogen atoms are shared by adjoining rings (Fig. 2). When a nitrogen atom substitutes for carbon in a hexagonal structure, it shares the same $\mathrm{sp}^{2}$-hybridization as neighboring carbon atoms, and its remaining two electrons participate in the delocalized $\pi$-electron network as described, for instance, in graphite (Dos Santos and Alvarez, 1998), fullerene (Reuther and Hirsch, 2000), and carbon nanotubes (Choi et al., 2005). Three-coordinated N prefers a locally 'buckled', non-planar structure. In principle, this promotes the formation of pentagons (Sjöström et al., 1995), but nitrogen can be accomodated in a hexagonal carbon network as long as the heteroatom concentration remains low (Hellgren et al., 1999).

Our study constrains thermal-evolutionary $\mathrm{N}_{\text {org }}$ pathways and strengthens our mechanistic understanding of metamorphic transformations of $\mathrm{N}_{\text {org }}$ leading to inorganic nitrogen species in fluids and residual $\mathrm{N}_{\text {org }}$-bearing carbonaceous matter. Although the emphasis of this study is placed on the geochemical fate of $\mathrm{N}_{\text {org }}$ during low-grade metamorphism up to the semigraphitic stage, it was necessary to also document the $\mathrm{N}_{\text {org }}$ inventory of some lower-maturity samples in order to properly cover the continuum between pre-metamorphism and metamorphism. Processes at even lower maturity, such as sedimentation of biomass and subsequent diagenesis, are beyond the scope of this paper.

\section{MATERIALS AND METHODS}

\subsection{Sample origin and vitrinite reflectance}

Samples from a wide range of ranks from anthracites to semi-graphites were collected from the Western Middle Anthracite Field of Pennsylvania, USA and from north German coal mines in the West European Carboniferous Basin (WECB) (Table 1).

This study utilizes mostly type III kerogens from coals (Table 1). We would have preferred to augment our coal-derived data with more data from kerogens types I and II, but no previously published nitrogen data are available at adequate thermal maturity. The few utilized kerogens of types I and II include:

Kerogen type I: A bright shungite from the upper Zaonezhskaya Formation near Lake Onega in the Shunga region of Karelia in Russia derives from one of the richest accumulations of organic material reported from the Proterozoic that generated one of the geologically earliest petroleums, probably from type I kerogen from algal or bacterial biomass (e.g., Mastalerz et al., 2000). Green River Shale contains type I kerogen and is the source rock of the primary petroleum system in the Uinta Basin (Utah, USA).

Kerogens type II derive from the New Albany Shale $(\mathrm{a} \leq 140 \mathrm{~m}$ thick horizon of Middle Devonian to Early Mississippian organic-rich shales) in the Illinois Basin (Werner-Zwanziger et al., 2005; Lis et al., 2006) covering a relatively wide range of maturity with vitrinite reflectance $\mathrm{R}_{\mathrm{o}}$ from 0.29 to $1.5 \%$ (Hasenmueller and Comer, 2000).

Vitrinite reflectance measurements $\mathrm{R}_{\text {mean }}$ and/or $\mathrm{R}_{\max }$ of bulk samples were performed according to standard methods (Stach et al., 1982; Daniels, 1992; Daniels and Altaner, 1990, 1993). Due to development of optical anisotropy at higher maturity, $R_{\max }$ is the preferred measure at vitrinite reflectance $>1.5 \%$. Most samples in this study have high rank and thus justify the consistent use of $R_{\max }$ values. An empirical conversion algorithm between $R_{\text {mean }}$ and $R_{\max }$ (given at the bottom of Table 1 ) is based on an extensive set of comparative $R_{\text {mean }}$ and $\mathrm{R}_{\max }$ measurements. 


\section{Table 1}

Sample identification, sample origin, age, maturity, elemental composition $(\mathrm{daf}=\mathrm{dry}$, ash-free $)$, stable isotope ratios, and nitrogen XPS data.

\begin{tabular}{|c|c|c|c|c|c|c|c|c|c|c|c|c|c|c|c|}
\hline \multirow{2}{*}{$\begin{array}{c}\text { Sample } \\
\#\end{array}$} & \multirow{2}{*}{$\begin{array}{c}\text { Kerogen } \\
\text { Type }\end{array}$} & \multirow{2}{*}{ Region } & \multirow{2}{*}{ Origin } & \multirow{2}{*}{ Age } & \multirow{2}{*}{$\begin{array}{c}R_{\max }{ }^{a} \\
(\%)\end{array}$} & \multicolumn{3}{|c|}{ Elemental Comp. (wt. \% daf) } & \multirow{2}{*}{$\mathrm{N}_{\min } \mathrm{c}$} & \multicolumn{2}{|c|}{$\underline{\mathrm{C}, \mathrm{N} \text { Isotopes (\%) }}$} & \multicolumn{4}{|c|}{ XPS Data $\left(\%\right.$ of total N) ${ }^{e}$} \\
\hline & & & & & & $\mathbf{C}_{\text {org }}$ & $\mathbf{N}_{\text {org }}$ & $\mathbf{N}_{\text {org }} / \mathbf{C}_{\text {org }}$ & & $\delta^{13} \mathrm{C}_{\text {org }}$ & $\delta^{15} \mathbf{N}_{\text {org }}$ & N-6 & N-5 & N-Q1 & $\mathbf{N}-\mathbf{Q} 2+\mathbf{N}-\mathbf{X}$ \\
\hline Sh & I & Karelia, Russia & Shungite & Precambrian & 6.80 & 95.5 & 0.7 & 0.006 & n.d. & -35.6 & 3.4 & 18.6 & 37.1 & 32.3 & 12.1 \\
\hline $472-1$ & II & Illinois Basin & New Albany Sh. & Mississippian & 0.33 & 74.6 & 2.7 & 0.031 & n.d. & -28.2 & -1.3 & 6.4 & 71.1 & 11.1 & 11.4 \\
\hline 634-1 & II & Illinois Basin & New Albany Sh. & Mississippian & 0.55 & 78.9 & 2.8 & 0.030 & n.d. & -30.9 & -0.3 & 16.6 & 65.3 & 11.5 & 6.6 \\
\hline IL-6 & II & Illinois Basin & New Albany Sh. & Mississippian & 0.76 & 81.6 & 2.3 & 0.024 & n.d. & -29.1 & 1.2 & 7.7 & 70.8 & 12.9 & 8.6 \\
\hline $450-1$ & II & Illinois Basin & New Albany Sh. & Mississippian & 0.84 & 82.3 & 2.4 & 0.025 & n.d. & -29.5 & -0.7 & 12.8 & 69.4 & 10.8 & 7.0 \\
\hline $376-2$ & II & Illinois Basin & New Albany Sh. & Mississippian & 1.32 & 85.8 & 2.6 & 0.026 & n.d. & -29.6 & -0.9 & 5.9 & 64.2 & 16.1 & 13.8 \\
\hline IL-2 & II & Illinois Basin & New Albany Sh. & Mississippian & 1.45 & 86.5 & 3.2 & 0.032 & n.d. & -29.3 & -0.9 & 11.1 & 70.8 & 14.9 & 3.3 \\
\hline$\# 8$ & III & North Dakota & Beulah-Zap & Tertiary & 0.32 & 72.9 & 1.2 & 0.014 & n.d. & n.d. & n.d. & 24.5 & 60.0 & 15.5 & 0.0 \\
\hline$\# 2$ & III & Wyoming & Wyodak-And. & Tertiary & 0.35 & 75.0 & 1.1 & 0.013 & n.d. & n.d. & n.d. & 25.0 & 60.0 & 15.0 & 0.0 \\
\hline$\# 3$ & III & Illinois & Illinois \#6 & Pennsylvanian & 0.50 & 77.7 & 1.4 & 0.015 & n.d. & n.d. & n.d. & 26.0 & 62.0 & 12.0 & 0.0 \\
\hline \#6 & III & Utah & Blind Canyon & Cretaceous & 0.55 & 80.7 & 1.6 & 0.017 & n.d. & n.d. & n.d. & 29.0 & 57.0 & 14.0 & 0.0 \\
\hline 115067 & III & NW Germany & Freya 1 & Pennsylvanian & 0.72 & 82.3 & 1.5 & 0.016 & n.d. & -24.2 & 3.1 & n.d. & n.d. & n.d. & n.d. \\
\hline$\# 4$ & III & Pennsylvania & Pittsburg \#8 & Pennsylvanian & 0.78 & 83.2 & 1.7 & 0.017 & n.d. & n.d. & n.d. & 32.0 & 61.0 & 7.0 & 0.0 \\
\hline$\# 7$ & III & Pennsylvania & Lewiston-St. & Pennsylvanian & 0.84 & 82.6 & 1.6 & 0.016 & n.d. & n.d. & n.d. & 31.0 & 60.0 & 9.0 & 0.0 \\
\hline 115076 & III & NW Germany & G 2 & Pennsylvanian & 0.97 & 84.3 & 1.4 & 0.015 & n.d. & -23.7 & 3.3 & 28.0 & 62.0 & 10.0 & 0.0 \\
\hline$\# 1$ & III & Pennsylvania & Upper Freeport & Pennsylvanian & 1.09 & 85.5 & 1.6 & 0.016 & n.d. & n.d. & n.d. & 29.0 & 64.0 & 7.0 & 0.0 \\
\hline 115083 & III & NW Germany & Ernestine & Pennsylvanian & 1.22 & 88.3 & 1.3 & 0.013 & n.d. & -23.8 & 3.3 & 32.6 & 58.3 & 9.1 & 0.0 \\
\hline 115070 & III & NW Germany & Zollverein 8 & Pennsylvanian & 1.31 & 86.6 & 1.7 & 0.017 & n.d. & -23.9 & 3.2 & 39.0 & 55.1 & 5.9 & 0.0 \\
\hline 115072 & III & NW Germany & Dickebank 1 & Pennsylvanian & 1.50 & 89.2 & 1.4 & 0.013 & n.d. & -23.7 & 2.4 & 32.0 & 60.0 & 8.0 & 0.0 \\
\hline 115075 & III & NW Germany & Dickebank 2 & Pennsylvanian & 1.55 & 88.1 & 1.3 & 0.013 & n.d. & -23.0 & 3.6 & 28.6 & 64.1 & 7.3 & 0.0 \\
\hline$\# 5$ & III & Virginia & Pocahontas \#3 & Pennsylvanian & 1.59 & 91.1 & 1.3 & 0.013 & n.d. & -23.2 & 4.5 & 28.7 & 63.4 & 5.6 & 2.4 \\
\hline 115078 & III & NW Germany & Finefrau 1 & Pennsylvanian & 2.08 & 89.9 & 1.3 & 0.012 & n.d. & -24.1 & 2.2 & 30.9 & 57.6 & 11.5 & 0.0 \\
\hline 115081 & III & NW Germany & Mausegatt 1 & Pennsylvanian & 2.50 & 92.0 & 1.4 & 0.013 & n.d. & -23.7 & 2.8 & 30.9 & 57.8 & 11.3 & 0.0 \\
\hline 7723 & III & NW Germany & Ibbenbüren & Pennsylvanian & 2.91 & 91.7 & 1.0 & 0.010 & 0.03 & -24.1 & 2.8 & 26.6 & 51.2 & 18.3 & 3.9 \\
\hline 115223 & III & NW Germany & Ibbenb. Flöz 48 & Pennsylvanian & 3.27 & 91.5 & 0.8 & 0.007 & 0.01 & -23.7 & 2.8 & n.d. & n.d. & n.d. & n.d. \\
\hline 115226 & III & NW Germany & Ibbenb. Flöz 52 & Pennsylvanian & 3.41 & 92.3 & 1.1 & 0.010 & 0.02 & -24.0 & 3.4 & n.d. & n.d. & n.d. & n.d. \\
\hline 7796 & III & NW Germany & Ibbenbüren & Pennsylvanian & 3.51 & 94.0 & 1.1 & 0.010 & 0.05 & -25.4 & 3.7 & 29.0 & 55.6 & 13.2 & 2.3 \\
\hline WM-RN & III & Pennsylvania & Little Orchard & Pennsylvanian & 3.78 & 93.4 & 1.3 & 0.012 & 0.03 & -25.8 & 5.1 & 25.0 & 59.0 & 11.3 & 4.7 \\
\hline 115233 & III & NW Germany & Ibbenb. Flöz 69 & Pennsylvanian & 3.88 & 94.2 & 1.0 & 0.009 & 0.02 & -24.6 & 2.6 & n.d. & n.d. & n.d. & n.d. \\
\hline 115229 & III & NW Germany & Ibbenb. Flöz 59 & Pennsylvanian & 4.22 & 93.7 & 1.2 & 0.010 & 0.07 & -23.7 & 3.1 & 26.5 & 62.0 & 11.5 & 0.0 \\
\hline 13493 & III & NW Germany & Ibbenbüren & Pennsylvanian & 4.27 & 94.0 & 1.0 & 0.009 & 0.03 & -24.0 & 2.7 & 25.0 & 53.0 & 12.1 & 9.9 \\
\hline 14488 & III & NW Germany & Ibbenbüren & Pennsylvanian & 4.72 & 94.7 & 1.0 & 0.009 & 0.05 & -23.3 & 3.0 & 22.6 & 51.0 & 16.5 & 9.9 \\
\hline WM-CR & III & Pennsylvania & Lykens & Pennsylvanian & 5.30 & 94.3 & 0.7 & 0.006 & 0.04 & -24.2 & 4.1 & 22.1 & 44.4 & 17.6 & 15.9 \\
\hline 1468 & III & Pennsylvania & Buck Mountain & Pennsylvanian & 5.45 & 95.4 & 0.6 & 0.005 & 0.12 & -24.2 & 5.0 & 16.5 & 28.9 & 25.0 & 29.7 \\
\hline 16H-LTA & III & Pennsylvania & WMAF $\mathbf{f}$ & Pennsylvanian & 5.66 & 95.6 & 0.0 & 0.000 & 1.50 & -24.4 & 4.8 & 4.2 & 10.6 & 0.6 & 84.5 \\
\hline 870 & III & Pennsylvania & Primrose & Pennsylvanian & 5.57 & 95.5 & 0.6 & 0.006 & 0.06 & -24.0 & 4.9 & 21.0 & 44.6 & 23.9 & 10.6 \\
\hline 751 & III & NW Germany & Piesberg & Pennsylvanian & 6.00 & 96.3 & 0.5 & 0.005 & 0.03 & -24.2 & 3.7 & 8.6 & 33.1 & 40.6 & 17.7 \\
\hline $2 \mathrm{C}$ & III & Pennsylvania & Buck Mountain & Pennsylvanian & 6.30 & 96.3 & 0.6 & 0.005 & 0.06 & -23.5 & 4.2 & 20.3 & 34.6 & 26.0 & 19.1 \\
\hline $19 \mathrm{~J}$ & III & Pennsylvania & Bernice & Pennsylvanian & 6.30 & 96.4 & 0.7 & 0.006 & 1.60 & -23.8 & 6.0 & 0.0 & 0.0 & 6.2 & 93.8 \\
\hline $17 \mathrm{C}$ & III & Pennsylvania & Buck Mountain & Pennsylvanian & 6.32 & 96.0 & 0.6 & 0.006 & 0.03 & -23.5 & 5.4 & 20.2 & 37.6 & 26.2 & 16.0 \\
\hline 6930 & III & NW Germany & Piesberg & Pennsylvanian & 7.00 & 97.4 & 0.4 & 0.004 & 0.03 & -24.1 & 3.6 & 13.5 & 36.8 & 32.4 & 17.3 \\
\hline 6770 & III & NW Germany & Piesberg & Pennsylvanian & 7.14 & 97.6 & 0.5 & 0.004 & 0.02 & -24.9 & 3.5 & 14.6 & 33.3 & 42.7 & 9.4 \\
\hline
\end{tabular}

(a) Below vitrinite reflectance values of $1.5 \%, \mathrm{R}_{\max }$ values were calculated from $\mathrm{R}_{\text {mean }}$ values using the following algorithm: $R_{\max }=-0.00387 \cdot R_{\text {mean }}^{3}+0.08533 \cdot R_{\text {mean }}{ }^{2}+0.97995 \cdot R_{\text {mean }}+0.03595 ; r^{2}=0.9971$.

(b) Determined on kerogen and expressed on a dry, ash-free basis (daf).

(c) $\mathrm{N}_{\min }$ is expressed with respect to the dry sample. For low rank samples $\mathrm{N}_{\min }$ was not determined (n.d.) and, prior to XPS analyses, samples were treated with $\mathrm{HF}-\mathrm{HCl}$ at room temperature to eliminate ammonium.

(d) Determined on kerogen; data from type III kerogens are from Gerling et al. (1997) and Ader et al. (1998a, 2006).

(e) XPS was performed either on ammonium-free substrates when $\mathrm{R}_{\max }<2.5 \%$, or on original dried samples at higher $\mathrm{R}_{\max }$.

(f) $\mathrm{WMAF}=$ Western Middle Anthracite Field, Pennsylvania, USA.

Grey highlighted rows indicate samples for which XPS analyses were performed on kerogen isolated from ammoniacontaining bulk shale (sample 19J) and on a mineral isolate from a meta-anthracite (sample $16 \mathrm{H}-\mathrm{LTA}$ ); $\mathrm{R}_{\max }, \mathrm{C}_{\text {org }}, \delta^{13} \mathrm{C}$ and $\delta^{15} \mathrm{~N}$ values for $16 \mathrm{H}-\mathrm{LTA}$ are those of the parent $16 \mathrm{H}$ meta-anthracite (16H was petrographically described by Daniels, 92). 


\subsection{Elemental, isotopic and thermal analyses}

Demineralization of rocks with acids inevitably causes some organic-geochemical alteration of the resulting kerogen isolate, especially in kerogens of lower rank. Our preparation of kerogens minimized organic-geochemical alteration by choosing standard techniques that are appropriate for various ranks. Each set of kerogen types was treated equivalently in order to maintain reproducibillity and comparability. Relatively low-rank New Albany Shale was processed for the preparation of kerogen using the chemically mild, lowtemperature $\mathrm{BF}_{3}$-HF method of Robl and Davis (1993), followed by heavy-liquid purification, washing, freeze-drying, and solvent extraction (Schimmelmann et al., 1999; Lis et al., 2006). Higher-rank rocks were demineralized with acids according to Durand and Nicaise's (1980) standard method.

Ammonium-silicates from high-rank samples (except the Karelian shungite) were separated from $\mathrm{N}_{\text {org }}$ and isolated as mineral nitrogen $\left(\mathrm{N}_{\min }\right)$ by low-temperature plasma ashing of powdered whole rock (Daniels and Altaner, 1990). Ammonium was liberated from the ash, or from the crude rock, via digestion in 1:1 vol/vol mixture of concentrated hydrofluoric and hydrochloric acids in polypropylene bottles overnight at room temperature, followed by the addition of aqueous $\mathrm{NaOH}$, distillation of $\mathrm{NH}_{3}$, and absorption of $\mathrm{NH}_{3}$ in dilute $\mathrm{H}_{2} \mathrm{SO}_{4}$ as ammonium sulfate. Ammonium $\mathrm{NH}_{4}{ }^{+}$was quantified colorimetrically by detection of indophenol blue at $690 \mathrm{~nm}$ using a Spectroquant spectrophotometer Nova 60 (Merck).

Analytical data from different studies are not always directly comparable due to differences among various wet-chemical digestion and combustion techniques (see Holloway and Dahlgren, 2002). Total $\mathrm{N}$ determination was therefore performed via complete Dumas combustion at high temperature in addition to ASTM D3179 (i.e., Kjeldahl-Gunning analysis) because wet-chemical methods are unable to fully digest $\mathrm{N}_{\text {org }}$ in metamorphic organic matter.

For most samples, $\delta^{13} \mathrm{C}_{\text {org }}$ values of organic carbon and $\delta^{15} \mathrm{~N}_{\text {org }}$ values of organic nitrogen were determined by sealed tube combustion and off-line isotope measurements using a Finnigan Delta $E$ mass spectrometer, with precisions of $\pm 0.05 \%$ and $\pm 0.15 \%$, respectively (Ader et al., 1998a) . Quality control of analyzed gases used scanning of $\mathrm{m} / \mathrm{z} 12,15,16,30$, 32 and $40(\mathrm{Ar}) . \delta^{13} \mathrm{C}_{\text {org }}$ and $\delta^{15} \mathrm{~N}_{\text {org }}$ values of type II kerogens were determined on-line using elemental analyzers coupled with Thermo Finnigan isotope ratio mass-spectrometers. $\delta^{13} \mathrm{C}$ and $\delta^{15} \mathrm{~N}$ values are reported in \%o notation relative to Vienna Peedee Belemnite (VPDB) and air nitrogen, respectively.

Bulk carbon and nitrogen isotopic compositions of selected original rocks containing no mineral carbon or nitrogen were indistinguishable from values of their kerogens. This serves as evidence that the preparation of kerogen did not isotopically fractionate $\mathrm{N}_{\text {org }}$. High temperature and long duration of plasma ashing can change the surface topography and the chemical composition of residual mica (Liu et al., 1997), possibly causing nitrogen isotopic fractionation due to partial loss of ammonia. However, we found that $\delta^{15} \mathrm{~N}_{\text {ammonium values of }}$ isolated ammonium were similar to $\delta^{15} \mathrm{~N}$ values that were calculated by isotopic mass-balance as the difference between measured $\mathrm{N}_{\text {total }}$ in original rock and measured $\mathrm{N}_{\text {org }}$ in kerogen. Assuming that $\mathrm{N}_{\text {total }}=\left(\mathrm{N}_{\text {org }}+\mathrm{N}_{\text {ammonium }}\right)$, these data suggest that no $\mathrm{N}_{\text {ammonium was lost during }}$ ammonium isolation and $\mathrm{N}_{\text {ammonium }}$ suffered little, if any isotopic fractionation.

For temperature-programmed pyrolysis mass-spectrometry (Boudou and Espitalié, 1995; Boudou et al., 2006), $\sim 5 \mathrm{mg}$ of a powdered sample with a grain size of $<80 \mathrm{~m}$ was placed in a crucible and heated from 100 to $1450{ }^{\circ} \mathrm{C}$ at $30^{\circ} \mathrm{C} \mathrm{min}^{-1}$ at atmospheric pressure in He with one volume $\% \mathrm{Ne}$ at a flow rate of $10 \mathrm{~cm}^{3} \mathrm{~min}^{-1}$. Product gases were continuously monitored 
and quantified with a Quadrex 100 Leybold quadrupole mass spectrometer. The $\mathrm{N}_{2}$ evolution profile was obtained by substracting interfering mass fragments of other gases from the $\mathrm{N}_{2}$ signal. The system was calibrated using gas mixtures in pure He with $1 \% \mathrm{Ne}$. The signal amplitude of each mass was compared to the m/z 20 signal amplitude of Ne. Physically desorbing water from heated samples produced a broad peak, probably due to interactions between polar water molecules and the inner walls of the transfer line between oven and detector. The integrated water peak was used to assess sample moisture content, and hence to correct gas yields with respect to organic carbon or total carbon content on a dry, ash-free basis.

Table 2

Structural assignments of XPS sub-peaks

\begin{tabular}{ccc}
$\begin{array}{c}\text { Sub- } \\
\text { peak }\end{array}$ & $\begin{array}{l}\text { Binding } \\
\text { energy }\end{array}$ & \multicolumn{1}{c}{ Structural assignments } \\
\hline Metamorphic nitrogen moieties
\end{tabular}

\section{Additional components from pre-metamorphic nitrogen moieties}

N-5 $400.6\left\{\begin{array}{l}\text { Pyrrolic or pyridinic nitrogen in rings with attached oxygen-containing } \\ \text { substituents (e.g. pyridone), or an oxygen atom substituting for a carbon in the } \\ \text { ring. } \\ \text { Amine }\end{array}\right.$

(a) Expressed in $\mathrm{eV}$ and calibrated with respect to the maximum principal $\mathrm{C} 1 \mathrm{~s}$ XPS sub-peak at $285 \mathrm{eV}$. 


\subsection{X-ray Photoelectron Spectroscopy}

During sample preparation for $\mathrm{N}$ 1s XPS analysis it is advantageous that $\mathrm{N}_{\text {org }}$ is less readily oxidized than carbon (Babich et al., 2005). In order to minimize surface oxidation artifacts, metamorphic rocks were freshly ground to $<80 \mu \mathrm{m}$ particle size in an automated agate mill. Powdered samples were pressure-mounted onto conducting indium foil. XPS signals were recorded using VG Scientific ESCALAB 220XL or 250 systems equipped with

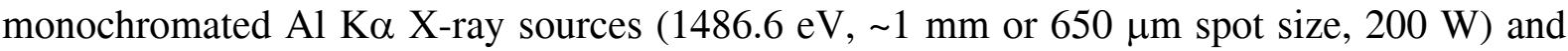
magnetic immersion lenses which focus electrons emitted from the sample over a cone of up to $45^{\circ}$ into the main lens column, thus enhancing sensitivity by several orders of magnitude. Spectra were acquired in constant analyzer energy mode, with pass energies of 150 and $40 \mathrm{eV}$ for survey and narrow regions, respectively. The $\mathrm{C} 1 \mathrm{~s}$ level binding energy (285 eV at the maximum of the principal $\mathrm{C}$ 1s component) was used to calibrate the binding energy scale. Binding energy values were determined with a precision of $\pm 0.1 \mathrm{eV}$. Binding energy values were not subject to charging effects, making it unnecessary to utilize the charge compensation system (i.e., a combination of electron and argon flood guns). After subtraction of background and satellite contributions, $\mathrm{N}$ 1s envelopes were curve-fitted with the minimum number of mixed Gaussian-Lorentzian component profiles. The Gaussian-Lorentzian mixing ratio (typically $20 \%$ Lorentzian and $80 \%$ Gaussian functions), the full width at half maximum, and the positions and intensities of peaks were left unconstrained to result in a best fit.

Chemical-structural assignments of N 1s XPS sub-peaks were guided by known binding energies of nitrogen in model compounds and purified substrates (studies cited in Table 2; NIST XPS database). Table 2 characterizes assignments of N-6, N-5, N-Q1, and N-X XPS peaks to structural $\mathrm{N}_{\text {org }}$ moieties. Ammonium salt is typically absent or negligible in bituminous and sub-bituminous coals. However, since ammonium salt traces may exhibit an $\mathrm{N}$ 1s XPS sub-peak at about $-401.4 \mathrm{eV}$, selected powdered samples were treated with $\mathrm{HF} / \mathrm{HCl}$ before XPS analysis to reduce the possible contribution from $\mathrm{N}_{\min }$ when the N-Q1 $\left(\mathrm{N}-\mathrm{C}_{3}\right)$ subpeak was small (HF/HCl-treated samples are identified in Table 1). The N-Q2 XPS peak for fixed ammonium occurs at relatively high binding energy (Table 2).

\section{RESULTS AND DISCUSSION}

\subsection{Elemental, rank, and isotopic characterization}

Maturity (rank), elemental composition, carbon and nitrogen stable isotope ratios, and the origin of samples are compiled in Table 1 . Vitrinite reflectance $R_{\max }(\%)$ is one of the best measures of low-metamorphic grade (e.g., Frey M., and Robinson D., 1999). Our data are plotted both as a function of $\mathrm{R}_{\max }$ and $\mathrm{C}_{\text {org }}$ (wt. \% on a dry, ash-free basis) because studies on nitrogen during coal/kerogen maturation typically relate changes in nitrogen chemistry to $\mathrm{C}_{\text {org }}$ content. Type II kerogens show higher $\mathrm{N}_{\text {org }} / \mathrm{C}_{\text {org }}$ ratios than type III kerogens at comparable maturities, and the $\mathrm{N}_{\text {org }} / \mathrm{C}_{\text {org }}$ ratio of type III kerogen decreases with increasing $\mathrm{C}_{\text {org }}$ (Fig. 3a) and $\mathrm{R}_{\max }$ (Fig 3b).

A cross-plot of $\delta^{15} \mathrm{~N}_{\text {org }}$ versus $\delta^{13} \mathrm{C}_{\text {org }}$ values (Fig. 4a) distinguishes shale kerogens from coal kerogens, with mean $\delta^{15} \mathrm{~N}_{\text {org }}$ values of $\sim 3 \%$ o for NW German coal fields and $\sim 5 \%$ or North American fields. Although our sample series cover a large range of ranks, $\delta^{13} \mathrm{C}_{\text {org }}$ and $\delta^{15} \mathrm{~N}_{\text {org }}$ values for type II and type III kerogens do not express strong shifts with increasing maturity within each type of kerogen (Fig. 4b), in agreement with earlier $\delta^{13} \mathrm{C}_{\text {org }}$ studies 
(Galimov, 1980; Lewan, 1986). $\delta^{13} \mathrm{C}_{\text {org }}$ and $\delta^{15} \mathrm{~N}_{\text {org }}$ values of type I kerogen from bright shungite are in agreement with previously published values (Melezhik et al., 1999; Mastalerz et al., 2000; Verchovsky et al., 2006). $\delta^{15} \mathrm{~N}_{\text {org }}$ values of type II kerogens (Fig. 4a) are typical for black shales where $\delta^{15} \mathrm{~N}$ is usually between -3 and $+2 \%$ o (e.g., Rau et al., 1987; Dumitrescu and Brassell, 2006; Meyers, 2006). This study's $\delta{ }^{15} \mathrm{~N}_{\text {org }}$ values of type III kerogens fall into the upper range of published $\delta^{15} \mathrm{~N}$ values for coals $(\sim 0$ to $+5 \%$; Boudou et al., 1984a; Burchill and Welch, 1989; Whiticar, 1996; Ader et al., 1998a; Rimmer et al., 2006).
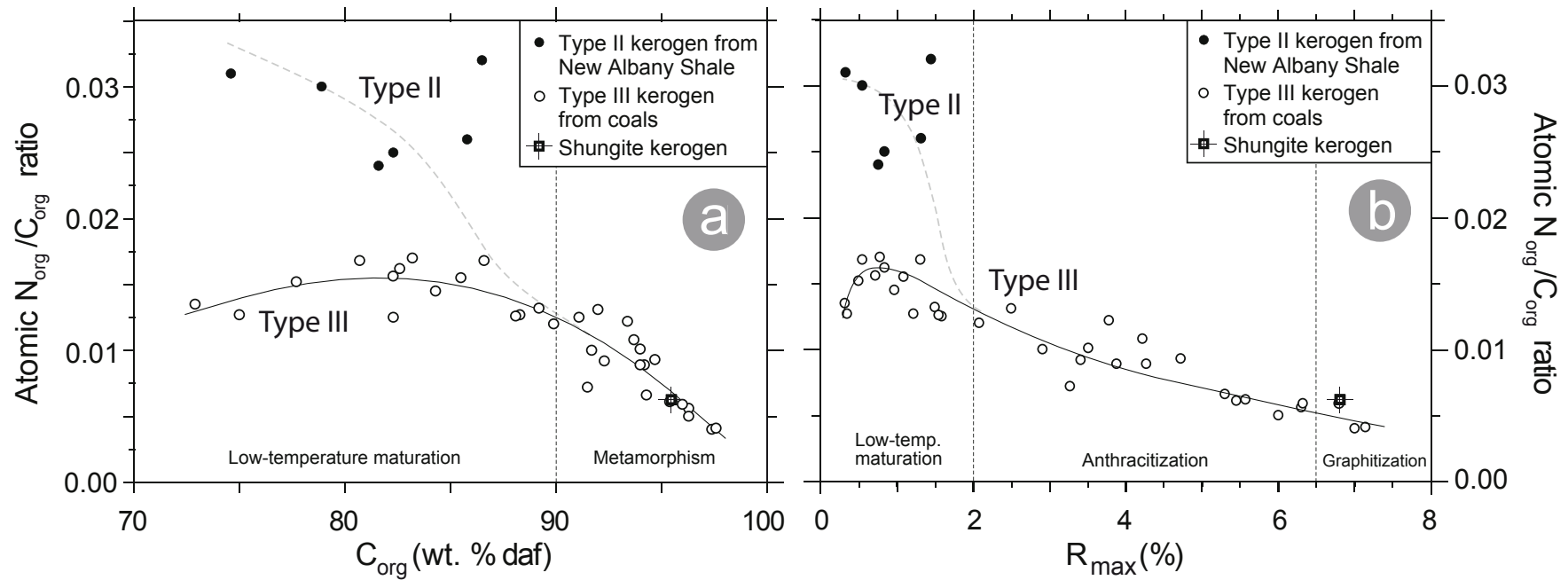

Fig. 3. Organic atomic $\mathrm{N}_{\text {org }} / \mathrm{C}_{\text {org }}$ ratios of kerogens plotted against (a) the organic carbon content in bulk rocks/coals (in weight \% on a dry, ash-free basis, daf), and (b) rank expressed by vitrinite reflectance $\mathrm{R}_{\max }(\%)$. Gray dashed lines represent expected trends for type II kerogens. Solid lines are drawn to guide the eye.
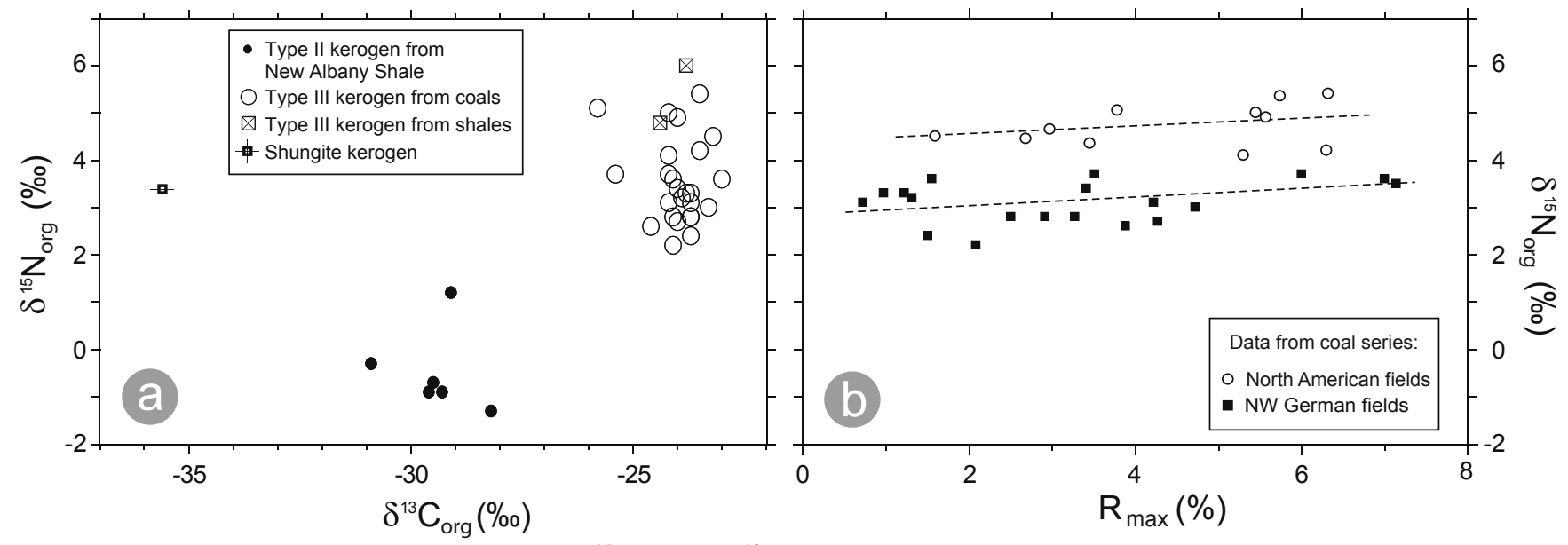

Fig. 4. (a) Stable isotopic cross-plot of $\delta^{15} \mathrm{~N}_{\text {org }}$ and $\delta^{13} \mathrm{C}_{\text {org }}$ values of kerogens from shales and coals, indicating distinct clustering of sample sets used in this study. (b) $\delta^{15} \mathrm{~N}_{\text {org }}$ values of kerogens from North American and NW German coal series do not express strong dependence on rank (i.e., vitrinite reflectance, $R_{\max } \%$ ). Dashed lines are drawn to guide the eye.

\subsection{Deconvolution of the N 1s XPS spectrum: Sub-peaks of inorganic and organic $N$}

\subsubsection{Inorganic nitrogen: $N$ 1s XPS of ammonium intercalated in clay}

In anthracite and meta-anthracite, ammonium may occur in embedded fine laminae of ammonium-illite in the organic matrix, as documented by scanning electron microscopy images and energy-dispersive X-radiography (SEM-EDX) of meta-anthracite 2C that is 
typical for the Western Middle Anthracite Field, Pennsylvania (Daniels, 1992; Ader et al., 1998a). The specific N 1s XPS spectral contribution of $\mathrm{NH}_{4}{ }^{+}$in bulk coal or rock samples is documented in synoptically shown spectra in Fig. 5c-f. Ammonium is abundant in bulk carbonaceous shale 19J (Fig. 5c, d). Ammonium-rich clay is also evident in the XPS spectra of low-temperature plasma-ashed residue of meta-anthracite 16H-LTA (Fig. 5e, f) where a small amount of Pocahontas \#3 coal had been admixed because some un-oxidized carbon is needed for internal calibration of the binding energy scale. Pocahontas \#3 coal was chosen because its N 1s XPS spectrum displays a small N-Q1 and weak N-Q2 and N-X sub-peaks (Fig. 6b). The N 1s XPS spectra of bulk shale 19J (Fig. 5d) and 16H-LTA (Fig. 5f) feature a main Lorentzian-Gaussian sub-peak N-Q2 around $402.7 \mathrm{eV}$ reflecting ammonium in illite that had also been identified by X-ray diffraction (Daniels, 1992). The presented N 1s XPS evidence for an ammonium contribution to sub-peak N-Q2 is corroborated by studies of Buckley et al. (1995, 1996) and Gong et al. (1999). The use of demineralized kerogens in our study eliminated mineral-hosted ammonium and facilitated the deconvolution of $\mathrm{N} 1 \mathrm{~s}$ XPS spectra in terms of the exclusive presence of organic nitrogen.

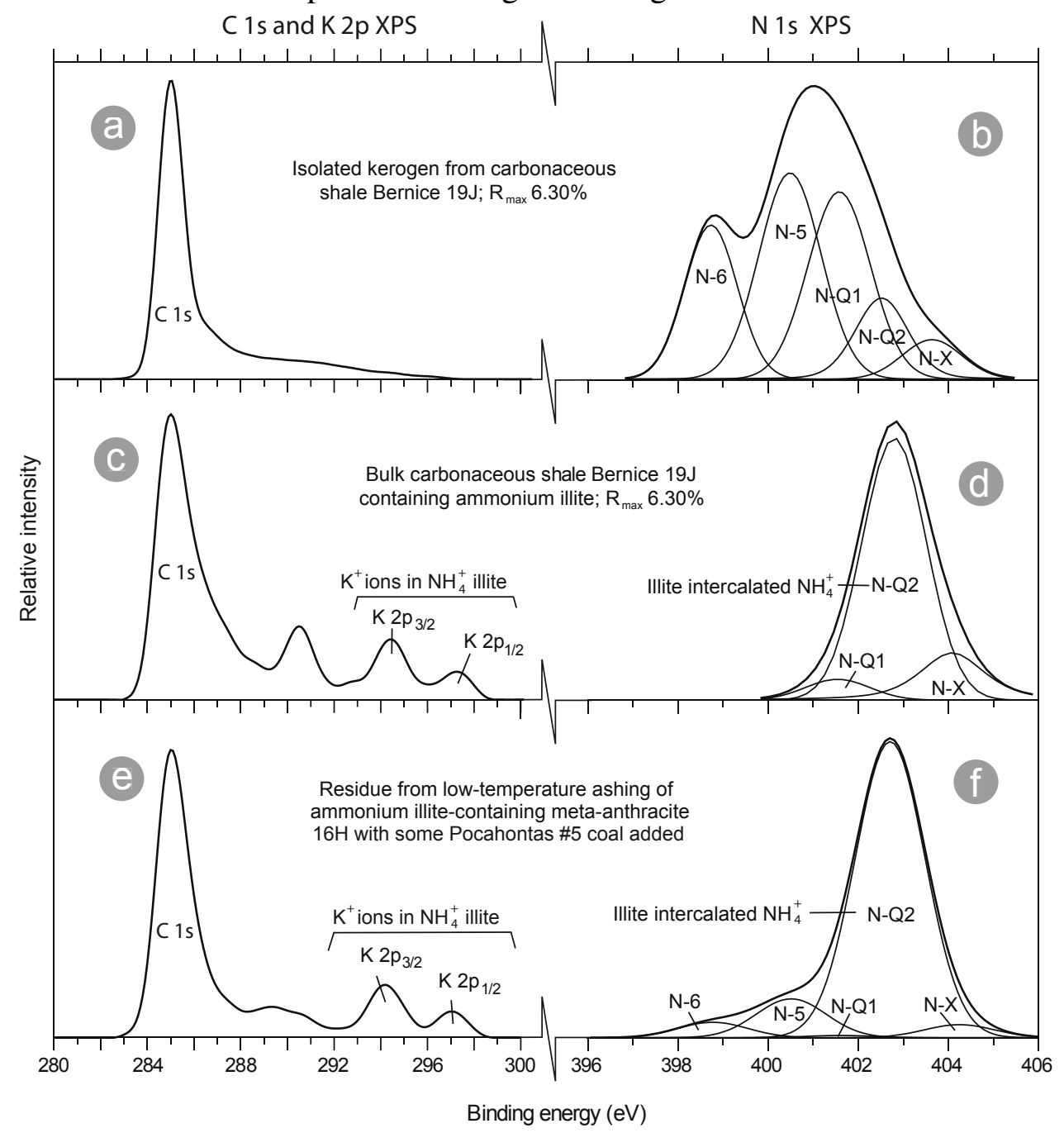

Fig. 5: N 1s XPS and C 1s XPS spectra with curve-fitted sub-peaks for: (a, b) kerogen isolated from carbonaceous shale Bernice 19J, a carbon-poor shale that was sampled close to an anthracite bed; (c, d) the same bulk carbonaceous shale Bernice 19J containing ammonium illite; and (e, f) the inorganic residue $16 \mathrm{H}$-LTA from low-temperature plasma ashing of meta-anthracite $16 \mathrm{H}$; the ash was mixed with a 
small amount of Pocahontas coal \#3 because some carbon is needed for calibration of the binding energy scale.

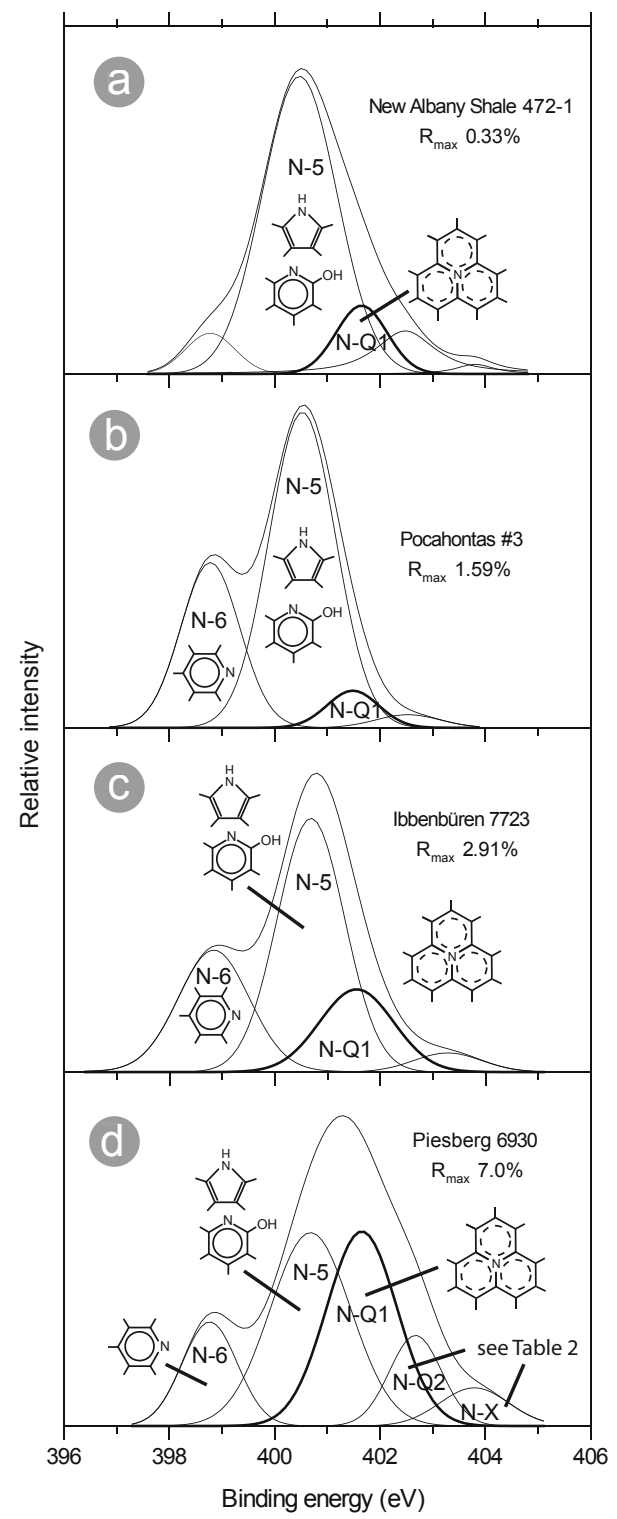

Fig. 6. N 1s XPS spectra with curve-fitted sub-peaks for four selected samples from low to high maturity (see Table 1 for preparation methods). Some sub-peaks are associated with exemplary chemical structures characterizing nitrogen moieties that are mainly responsible for observed XPS signals.

\subsubsection{Sub-peak N-Q1: Organic $N-C_{3}$}

The N 1s XPS sub-peak N-Q1 with a mean binding energy of $401.6 \mathrm{eV}$ and mean full width at half-maximum (FWHM) $=1.6 \mathrm{eV}$ is assigned to $\mathrm{N}-\mathrm{C}_{3}$ where each $\mathrm{N}$ atom is bonded covalently to three $\mathrm{C}$ atoms (Figs. 2, 6 and 7). The higher binding energy of $\mathrm{N}-\mathrm{C}_{3}$ relative to two-coordinated nitrogen (i.e., each $\mathrm{N}$ atom bonded to two carbon atoms, as in pyridine and pyrrole rings; Table 2) is partly attributed to electron charge transfer from $\mathrm{C}$ to $\mathrm{N}$ (Boutique et al., 1984). The predominant association of $\mathrm{N}-\mathrm{Q} 1$ with $\mathrm{N}-\mathrm{C}_{3}$ (Pels et al., 1995) in metamorphic samples is indicated by a strong increase in the relative abundance of N-Q1 with rank increase (Figs. 7e, f, 8c, d, ) after hydroxyl and carboxyl groups have long been eliminated (Blom et al., 1957; van Krevelen, 1961). 

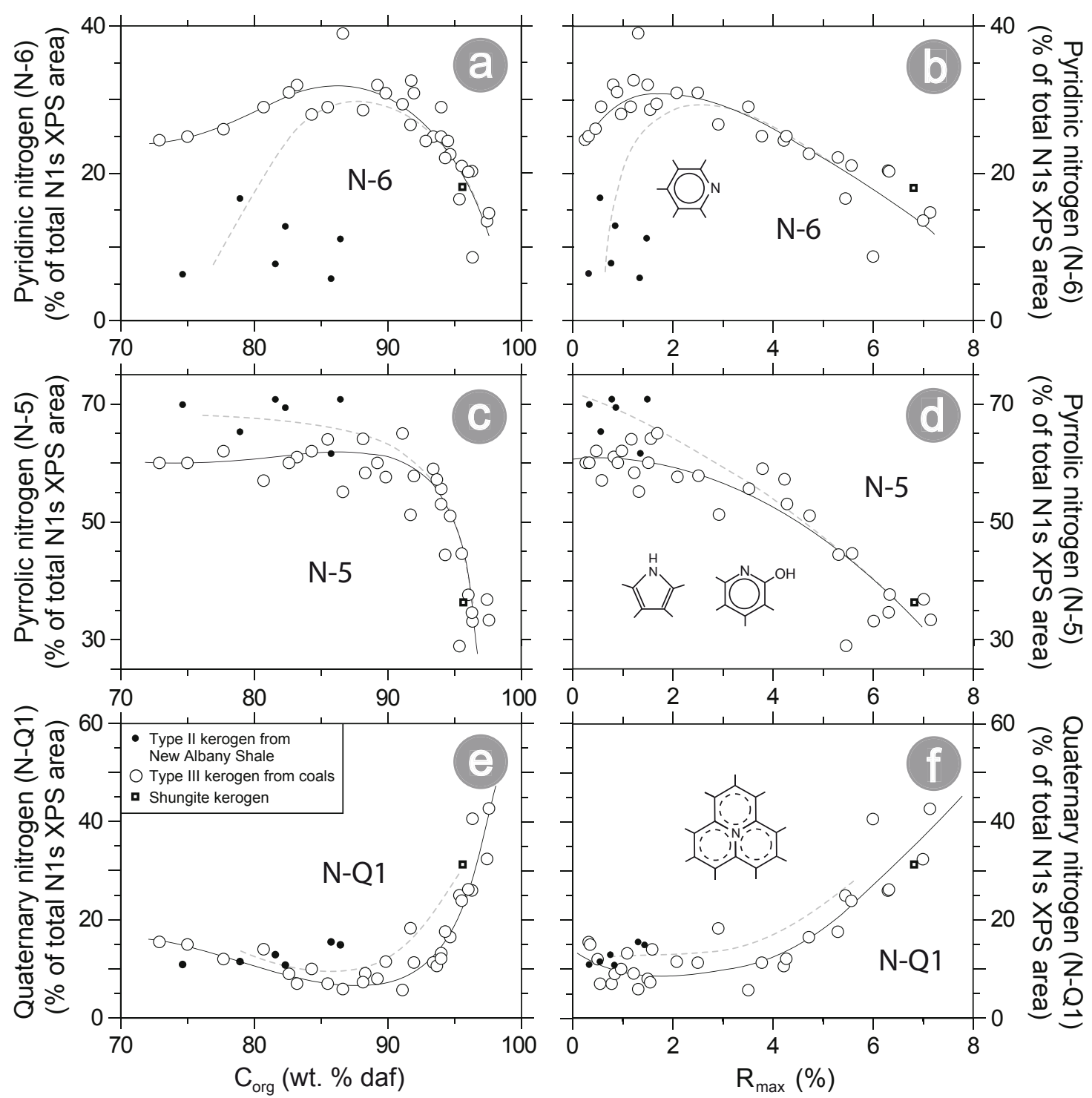

Fig. 7. Dependence of pyridinic $(\mathbf{a}, \mathbf{b})$, pyrrolic $(\mathbf{c}, \mathbf{d})$, and quaternary/cyclazine-type nitrogen $(\mathbf{e}, \mathbf{f})$ moieties on organic carbon content and vitrinite reflectance $\mathrm{R}_{\max }(\%)$. The resulting patterns over maturity depend on the proxy for rank; the $\mathrm{C}_{\text {org }}$ content is appropriate for samples with lower maturity, whereas the use of $\mathrm{R}_{\max }$ is preferred throughout metamorphism to a semi-graphitic stage. Each organic nitrogen moiety is quantified in terms of the area of its diagnostic XPS sub-peak N-6, N-5, or N-Q1 relative to the overall XPS N 1s signal area. The organic carbon content $\mathrm{C}_{\text {org }}$ is expressed as weight $\%$ on a dry, ash-free basis (daf). Vitrinite reflectance is given as $\mathrm{R}_{\max }(\%)$. Solid lines are drawn to guide the eye. Dashed gray lines indicate hypothetical trends for type II kerogen, assuming that the evolutionary paths of type II and III kerogens converge during metamorphism. Panels (b), (d) and (f) also offer exemplary chemical structures characterizing nitrogen moieties that are mainly responsible for observed XPS signals.

Trace amounts of quaternary nitrogen in the pre-metamorphic stage reflect a form of pyridinic nitrogen associated with adjacent or nearby hydroxyl or carboxyl groups that are protonated via formation of H-bridges (Kelemen et al., 1999; see structural example in Table 2). Quaternary nitrogen XPS peaks in some materials may also reflect the presence of ammonium salts (Gong et al., 1997; NIST XPS database) and protonated amines (e.g., Clark et al., 1976; Vidyadhar et al., 2003), although this has limited relevance for coals and kerogens where these species are essentially absent. 


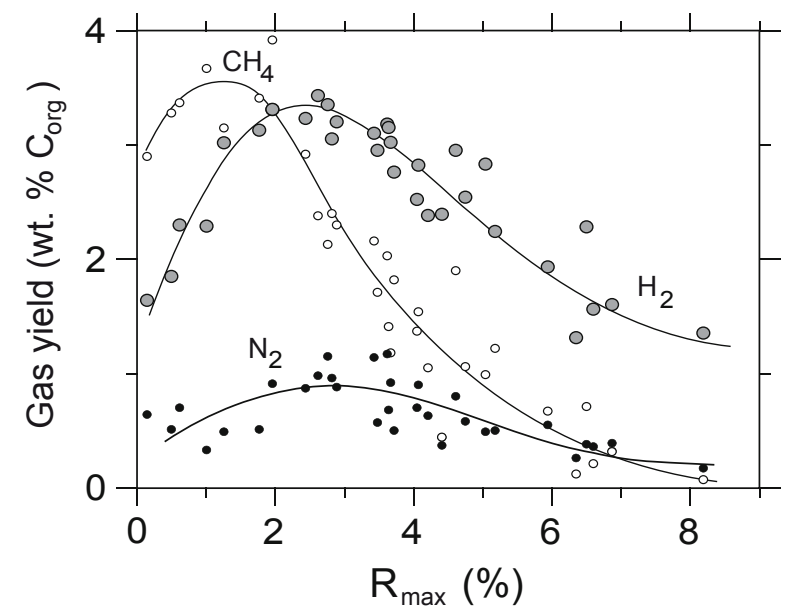

Fig. 8. Temperature-programmed pyrolysis of coal at temperatures up to $1450{ }^{\circ} \mathrm{C}$ produces nitrogen $\left(\mathrm{N}_{2}\right)$, methane $\left(\mathrm{CH}_{4}\right)$, and hydrogen $\left(\mathrm{H}_{2}\right)$. Data from a coal reference series (Boudou and Espitalié, 1995) exhibit distinct patterns of gas yields that are expressed in $\mathrm{mg}$ of $\mathrm{CH}_{4}, \mathrm{~N}_{2}$ and $\mathrm{H}_{2}$ per $100 \mathrm{mg}$ of total organic carbon content in the analyzed sample. Thermal maturity is expressed as vitrinite reflectance $\mathrm{R}_{\max }(\%)$.
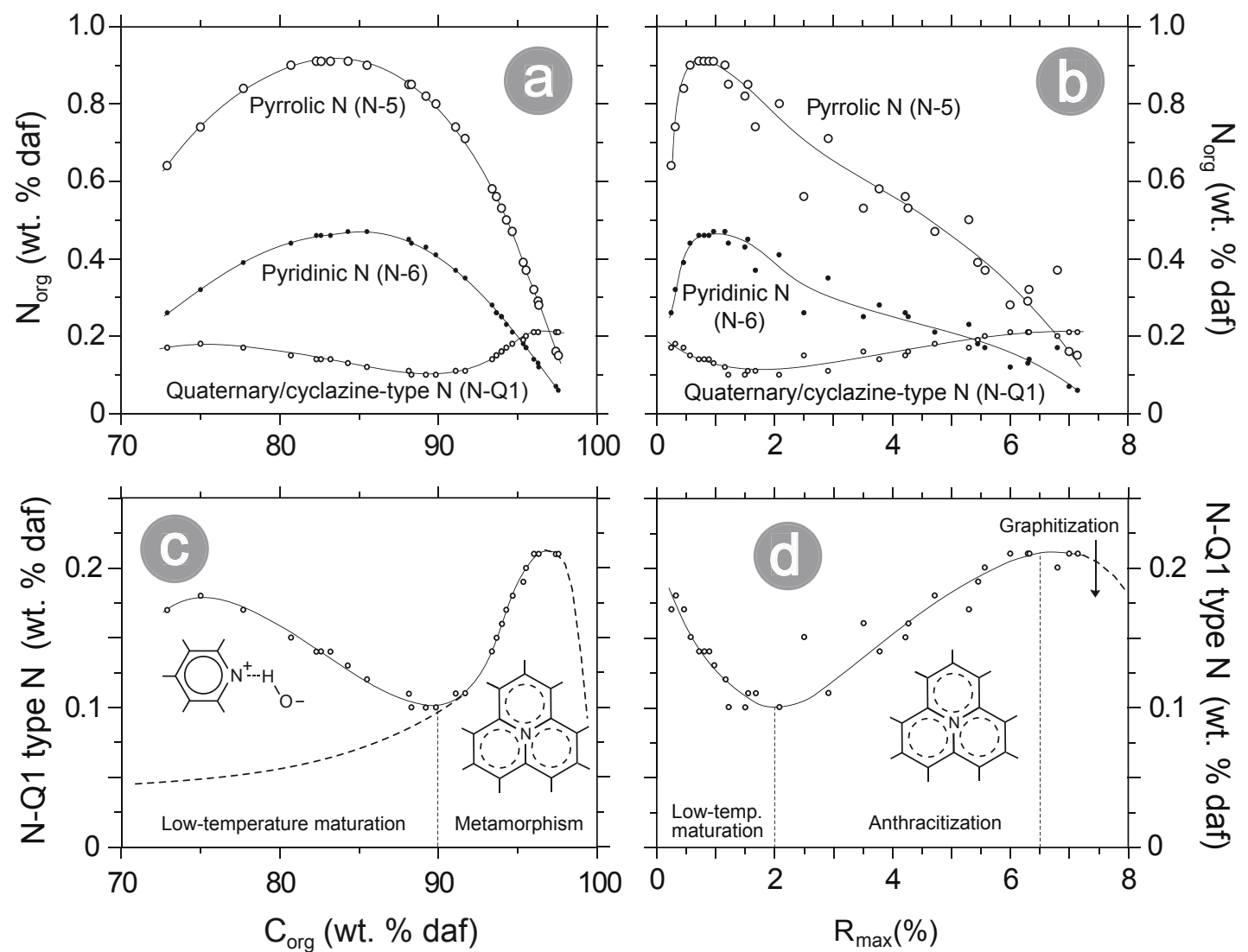

Fig. 9. The concentration of organic nitrogen $\mathrm{N}_{\text {org }}$ moieties (in weight $\%$ on a dry, ash-free basis, daf) in a series of type III kerogens is plotted relative to (a) organic carbon content $\left(\mathrm{C}_{\mathrm{org}}\right.$, wt. \% daf) and (b) vitrinite reflectance $\mathrm{R}_{\max }(\%)$. The resulting patterns over maturity depend on the proxy for rank; the $\mathrm{C}_{\mathrm{org}}$ content is appropriate for samples with lower maturity, whereas the use of $\mathrm{R}_{\max }$ is preferred throughout metamorphism to a semi-graphitic stage. Pyridinic, pyrrolic, and $\mathrm{N}_{-} \mathrm{C}_{3}$ were quantified via their diagnostic XPS sub-peaks N-6, N-5, and N-Q1, respectively, relative to the overall XPS N 1s signal and the known total nitrogen content (determined via elemental analysis). Panels (c) and (d) express N-Q1-related data in more detail and associate distinct peaks with specific $\mathrm{N}_{\text {org }}$ moieties relating to increasing thermal maturity. Solid lines are drawn to guide the eye. The dashed line in panel (c) represents a theoretical slow increase in $\mathrm{N}_{\text {org }}$ that is covalently bonded within condensed, partially aromatic systems (chemical-structural explanations offered in Table 2). 


\subsubsection{Sub-peaks $N-Q 2$ and $N$-X: Uncertain $N_{\text {org }}$ assignments}

In contrast to $\mathrm{N} 1 \mathrm{~s}$ XPS sub-peaks N-6, N-5 and N-Q1, the chemical-structural assignment of the weak high-binding energy sub-peaks $>402 \mathrm{eV}$ still remain unresolved (Fig. 6). Candidates for generating the N-Q2 sub-peak at $402.7 \mathrm{eV}(\mathrm{FWHM}=1.5 \mathrm{eV})$ and the $\mathrm{N}-\mathrm{X}$ sub-peak at $403.6 \mathrm{eV}(\mathrm{FWHM}=1.5 \mathrm{eV})$ are (i) pyridinic nitrogen atoms bonded to oxygen atoms, (ii) nitrogen substituting for carbon in condensed, partially aromatic systems (a higher nitrogen binding energy would arise both from charge transfer and hybridization; Casanovas et al., 1996), and (iii) ammonium fixed in clays (Fig. 5; Buckley et al., 1995, 1996; Gong et al., 1999) where the outermost sheet is composed of oxygen anions inducing a particular local interlayer environment, in contrast to simple ammonium salts ( $\mathrm{Yu}, 2007 ; \mathrm{He}$ et al., 2007). Kerogen does not contain any silicate minerals that can host ammonium, therefore the N 1s XPS N-Q2 and N-X sub-peaks of kerogen from the meta-anthracitecontaining shale $19 \mathrm{~J}$ cannot be caused by clay-bound $\mathrm{NH}_{4}^{+}$(Fig. 5b). The corresponding potassium K 2p XPS spectrum confirms the absence of illite (Fig. 5a). The N-X sub-peak in Fig. 5b may relate to organic $R=\mathrm{N}-\mathrm{O}-\mathrm{R}$ where nitrogen is linked to carbon $(R)$ and to one oxygen atom (e.g., Gong et al., 1999; Xiao al., 2005).

Although anthracites contain a network of closed micropores (Fryer, 1981; Mahajan, 1984; Daulan et al., 1998; Radlinski et al., 2004) that may originally contain some nitrogen gas, Boudou and Espitalié (1995) showed that elemental nitrogen is removed from micropores by crushing and evacuation. The mean relative peak areas of N-Q2 and N-X are $\sim 9 \%$ to $10 \%$ and $\sim 6 \%$ to $7 \%$ of the total N 1s XPS area, respectively. The presence of N-Q2 and N-X sub-peaks in kerogen from carbonaceous shale 19J (Fig. 5b) documents that these sub-peaks can largely originate from nitrogen species other than $\mathrm{NH}_{4}{ }^{+}$in minerals. In agreement with the presence of significant sulfur S 2p XPS peaks relating to sulfate, relatively low-rank New Albany Shale type II kerogens exhibit N-Q2 and N-X sub-peaks that could result from oxidation during preparation and storage rather than from a significant abundance in $\mathrm{N}-\mathrm{C}_{3}$.

\subsubsection{Sub-peak N-6: Contribution from pyridinic nitrogen}

Sub-peak N-6 corresponds to nitrogen expressing a mean binding energy of $398.8 \mathrm{eV}$ with a FWHM $=1.6 \mathrm{eV}$. It is associated with pyridinic nitrogen (Fig. 6), as well as with a few other nitrogen species, possibly including ammonia $\mathrm{NH}_{3}$. Good accuracy of the binding energy calibration of our $\mathrm{N} 1 \mathrm{~s}$ spectra is indicated by the gap $\Delta|\mathrm{N} 1 \mathrm{~s}-\mathrm{C} 1 \mathrm{~s}|$ between the binding energies of pyridinic nitrogen and carbon when the $\mathrm{C} 1 \mathrm{~s}$ signal is calibrated to $285 \mathrm{eV}$ at the maximum of the $\mathrm{C} 1 \mathrm{~s}$ envelope. Pyridinic nitrogen atoms are bonded only to two $\mathrm{C}$ atoms in an aromatic $\pi$-electron system. The observed $113.8 \mathrm{eV}$ offset $\Delta|\mathrm{N} 1 \mathrm{~s}-\mathrm{C} 1 \mathrm{~s}|$ is in agreement with reported values for pyridinic model compounds, such as 3,5,11,13tetraazacycl-[3,3,3]-azine or pyrolysates of acridine, 9-aminoacridine, 9-cyanoanthracene, 2aminoanthracene, poly(vinylpyrrolidone), and phenazine (reviewed by Lahaye et al., 1999). Temperature-programmed pyrolysis of anthracites demonstrated the absence of $\mathrm{NH}_{3}$ in closed micropores, although traces of $\mathrm{N}_{2}$ were found in meta-anthracite (Boudou and Espitalié, 1995). During the pre-metamorphic stage, the relative importance of the N-6 sub-peak area (as a percentage of the total $\mathrm{N} 1 \mathrm{~s}$ XPS peak area) increases up to a rank corresponding to $\sim 85$ wt. \% carbon (Fig. 7a). During subsequent anthracitization-graphitization, the relative abundance of N-6 nitrogen strongly decreases (Fig. 7b). This metamorphic decrease of N-6 parallels the decline of the atomic H/C ratio (van Krevelen, 1961) and lowered yields of molecular hydrogen during temperature-programmed pyrolysis (Fig. 8). 


\subsubsection{Sub-peak N-5: Pyrrolic and pyridinic rings with or without oxygen-containing substituents}

$\mathrm{N}$ 1s XPS sub-peak N-5 corresponds to nitrogen expressing a mean binding energy of $400.6 \mathrm{eV}$ with $\mathrm{FWHM}=1.7 \mathrm{eV}$ (Fig. 6). Its intensity hardly varies during the premetamorphic stage until $\mathrm{C}_{\text {org }} \sim 90 \mathrm{wt}$. $\%$, followed by a strong decrease above $\mathrm{R}_{\max } 2 \%$ during anthracitization-graphitization (Figs. 9c, 8a). The N-5 signal has been associated with three types of organic nitrogen. (i) Pyrrolic $\mathrm{N}$ atoms are bonded to one $\mathrm{H}$ atom and two $\mathrm{C}$ atoms in a non-aromatic or partially aromatic ring, with or without oxygen-containing substituents. (ii) Aromatic pyridinic rings contain $\mathrm{N}$ atoms in addition to oxygen-containing substituents (e.g., hydrated pyridinic rings, pyridone and pyridine carboxylic acids; defined by Mitra-Kirtley et al., 1993; Zhu et al., 1997; Vairavamurthy and Wang, 2002; Schnadt et al., 2003). Oxygencontaining substituents, such as hydroxyl groups, may provide chemically active sites for ring opening and subsequent elimination of $\mathrm{N}_{\text {org }}$ (Katritzky et al., 1997; Siskin and Katritzky, 2000). (iii) Amine and amide moieties may be present in less mature coals and kerogens (Kelemen et al., 2006). Within the accuracy of XPS measurements, pyridone nitrogen cannot be distinguished from pyrrolic nitrogen (Zhu et al., 1997). Similar to pyridinic nitrogen, these reactive nitrogen species are primarily located along the edge of condensed and partially aromatic systems.

\subsection{Organic nitrogen loss during low-grade metamorphism}

The scope and goals of this study of metamorphic transformation of kerogen and carbonaceous matter justify the reduced emphasis on kerogens of type I (i.e., lipid-rich organic matter from aquatic organisms) and type II, because with increasing thermal maturity the geochemical properties of different types of kerogens approach each other and eventually become indistinguishable. For example, at high rank with $\mathrm{C}_{\mathrm{org}}>97 \mathrm{wt} . \%$ and an atomic $\mathrm{H} / \mathrm{C}$ ratio $<0.4$, the composition of carbonaceous organic matter is narrowly predicted by van Krevelen's (1961) H/C and O/C diagrams, regardless of prior kerogen maturation paths of types I, II, or III (Tissot et al., 1974; Durand and Monin, 1980). This principle is evident in Fig. 3 where shungite type I kerogen is very similar to type III kerogens from coals of comparable rank.

At high rank, the carbonaceous matter includes insoluble kerogen and small amounts of extractable bitumen. Kerogen becomes increasingly aromatic whereby smaller aromatic ring structures condense to larger polyaromatic clusters that eventually mimic nanographitic sheets and eventually approach a well-ordered graphitic structure (Oberlin, 1984; Beyssac et al., 2002).

The thermal evolution of atomic $\mathrm{N}_{\text {org }} / \mathrm{C}_{\text {org }}$ ratios of type III kerogen can be divided into three stages when viewed as a function of the $\mathrm{C}_{\text {org }}$ concentration (Fig. 3a), or of vitrinite reflectance $R_{\max }$ (Fig. $3 b$ ). First, a relative enrichment of $\mathrm{N}_{\text {org }}$ in kerogen occurs due to preferential loss of carbon, hydrogen and oxygen during diagenesis and maturation into the early oil window corresponding to $\mathrm{C}_{\text {org }}$ below $\sim 85$ wt. $\%$ daf (Figs. 1, 3a). Subsequent loss of $\mathrm{N}_{\text {org }}$ from kerogen results in decreasing $\mathrm{N}_{\text {org }} / \mathrm{C}_{\text {org }}$ ratios from the end of the oil window to the onset of the dry gas window of thermogenic methane generation (corresponding to $\mathrm{R}_{\max } \sim 2 \%$; Figs. 1, 3b; Boudou and Espitalié, 1995). Finally, the observation of very low $\mathrm{N}_{\text {org }}$ contents in semi-graphite and graphite (Ader et al., 2006) suggests extensive loss of $\mathrm{N}_{\text {org }}$ during semigraphitization and graphitization. Our $\mathrm{N}_{\text {org }} / \mathrm{C}_{\text {org }}$ data support an earlier conceptual evolutionary path for $\mathrm{N}_{\text {org }}$ in type III kerogen where an early phase of relative $\mathrm{N}_{\text {org }}$ accumulation is followed by a phase of metamorphic $\mathrm{N}_{\text {org }}$ loss (Boudou et al., 1984a, b; 
Boudou and Espitalié, 1995). Our findings are also corroborated by recent data from German Creek and Moranbah Coal measures of the Bowen Basin in Australia where total nitrogen concentrations start a significant decrease at $\mathrm{R}_{\max } \sim 2 \%$ (Ward et al., 2005).

\subsection{Mechanism for organic nitrogen loss without isotope fractionation}

In spite of a significant loss of $\mathrm{N}_{\text {org }}$ (Fig. 3), the natural maturation path of type III kerogens does not produce large $?^{15} \mathrm{~N}_{\text {org }}$ variation or trends over a wide range of vitrinite reflectance values (Fig. 4b). Limited or absent $?{ }^{15} \mathrm{~N}_{\text {org }}$ isotope fractionation with thermal maturation has been observed in previous studies of type III kerogen (Boudou et al., 1984a, b; Rigby and Batts, 1986; Whiticar, 1996; Ader et al., 1998a, 2006). The limited $?^{15} \mathrm{~N}_{\text {org }}$ data for type I and II kerogens determined in this study are insufficient to reach the same conclusions as for type III kerogen (Table 1).

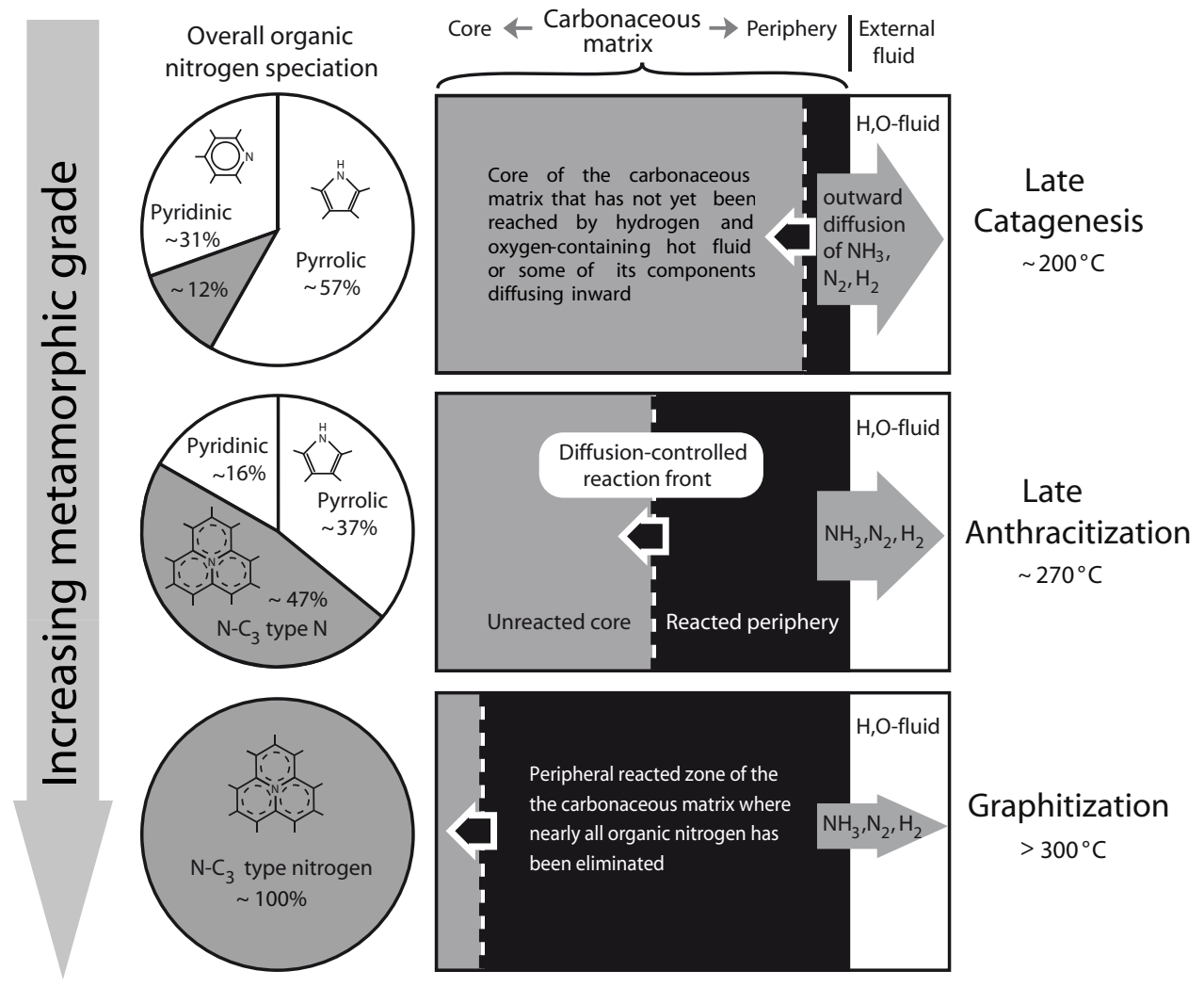

Fig. 10. Proposed idealized transformations of organic nitrogen during low-temperature maturation and metamorphism: Hot H, O-containing fluids or some of their components gradually penetrate toward the core of a dense and ultra-microporous carbonaceous matrix. The resulting reactions between fluid components and organic nitrogen lead to the elimination of organic nitrogen along a reaction front, generating a nitrogendepleted peripheral reacted zone (black). Liberated ammonia and some elemental nitrogen diffuse out of the carbonaceous matrix. Before the reaction front can reach deeply embedded 'core' nitrogen in the interior of the carbonaceous matrix (grey part of rectangles), an increasing fraction of core nitrogen chemically stabilizes as single nitrogen atoms substituting for carbon in condensed and partially aromatic systems (i.e., $\mathrm{N}-\mathrm{C}_{3}$ ). With ongoing thermal chemical evolution, the chemical speciation of the remaining bulk organic nitrogen changes distinctly. Pie charts indicate average relative abundances of pyridinic $\mathrm{N}$, pyrrolic $\mathrm{N}$, and $\mathrm{N}-\mathrm{C}_{3}$ nitrogen substituting for carbon inside the condensed and partially aromatic systems for late catagenesis, late anthracitization, and graphitization. Temperature ranges are adopted from estimates for Pennsylvania's anthracite fields and other ones (see Fig. 1; Hower and Gayer, 2002; and refs. therein). 
Several reasons may account for the conservative character of $\delta^{15} \mathrm{~N}_{\text {org }}$ during thermal evolution. (i) Some nitrogen-containing heterocycles express remarkable thermal stability, especially structures containing $\mathrm{N}_{-} \mathrm{C}_{3}$. (ii) All isotope fractionations tend to decrease with increasing temperature. However, even high pyrolysis temperatures in the laboratory are unable to eliminate isotopic fractionation during thermal disproportionation of $\mathrm{N}_{\text {org }}$ from coal (e.g., Stiehl and Lehmann, 1980). (iii) Nitrogen isotope exchange between $\mathrm{N}_{\text {org }}$ in source rocks and $\mathrm{NH}_{4}{ }^{+}$in aqueous fluids has been observed in hydrous pyrolysis experiments (Schimmelmann et al., 1998) and buffers $\delta^{15} \mathrm{~N}_{\text {org }}$ values if the available pool of $\mathrm{NH}_{4}{ }^{+}$is large relative to that of $\mathrm{N}_{\text {org }}$. Formation fluids contain abundant and mobile aqueous $\mathrm{NH}_{4}{ }^{+}$(e.g., Manning and Hutcheon, 2004) until metamorphism reaches stability fields where ammonium ions and ammonia are no longer stable in the free fluid phase (e.g., Hallam and Eugster, 1976; Andersen et al., 1993). The effect of isotopic buffering of $\delta^{15} \mathrm{~N}_{\text {org }}$ would extend into the temperature range of metamorphism if $\mathrm{NH}_{3}$ or $\mathrm{NH}_{4}{ }^{+}$can penetrate into ultramicroporous carbonaceous grains. Regardless of the contributing factors, the observed small variance of $\delta^{15} \mathrm{~N}_{\text {org }}$ before and during metamorphism (Fig. 4b) in the presence of a large and progressive loss of $\mathrm{N}_{\text {org }}$ (Fig. 3) calls for essentially non-fractionating mechanisms of $\mathrm{N}_{\text {org }}$ elimination.

Simple thermal degradation would isotropically affect all sites of a carbonaceous solid phase simultaneously and would likely entail Rayleigh-type isotope fractionation in the residual $\mathrm{N}_{\text {org }}$, as observed during experimental coal pyrolysis (e.g., Stiehl and Lehmann, 1980) or oil formation (e.g., Oldenburg et al., 2007). The mechanism of our proposed nonfractionating loss of $\mathrm{N}_{\text {org }}$ during metamorphism is depicted in Fig. 10. In brief, the overall isotope ratio of $\mathrm{N}_{\text {org }}$ in the carbonaceous matrix remains constant when $\mathrm{N}_{\text {org }}$ is eliminated along a reaction front that proceeds through the carbonaceous matrix. Progress along the reaction front in the absence of overall isotope fractionation requires (i) diffusive transport of hot $\mathrm{H}$, O-containing fluids or some of their components towards the interior of the carbonaceous matrix, (ii) a relatively fast and essentially complete conversion of $\mathrm{N}_{\text {org }}$ to inorganic nitrogen species along the reaction front, and (iii) diffusive removal of reaction products $\mathrm{NH}_{4}{ }^{+}$and $\mathrm{N}_{2}$ out of the reacted zone. In other words, essentially all $\mathrm{N}_{\text {org }}$ is located in the unreacted core of the carbonaceous matrix and its $\delta^{15} \mathrm{~N}_{\text {org }}$ value is relatively constant and equal to bulk $\delta^{15} \mathrm{~N}_{\text {org }}$. The following sections will discuss details about the stabilization of $\mathrm{N}_{\text {org }}$ as $\mathrm{N}-\mathrm{C}_{3}$ in the core of the carbonaceous matrix, and the role of hot fluids in the chemical transformation of $\mathrm{N}_{\text {org }}$.

\subsection{Increase of $\mathrm{N}-\mathrm{C}_{3}$ substituting for carbon in condensed, partially aromatic systems, at the expense of edge-located organic nitrogen}

This study provides the first direct evidence for organic nitrogen atoms substituting for "graphitic" carbon in natural metamorphic organic matter. With increasing thermal maturity, chemically less stable $\mathrm{N}_{\text {org }}$ functional groups and $\mathrm{N}$-containing heterocycles are eliminated or transformed to more stable moieties. These chemical changes with increasing rank are reflected by changes in the relative areas of N 1s XPS sub-peaks (Fig. 7). The XPS signals from distinct $\mathrm{N}_{\text {org }}$ moieties can also be expressed in terms of weight percent of participating nitrogen as a function of rank (Fig. 9).

Our data indicate that, at the metamorphic onset at $\mathrm{C}_{\text {org }} \sim 90 \mathrm{wt} . \%$ (daf) and $\mathrm{R}_{\max } 2 \%, \mathrm{~N}_{\text {org }}$ is mainly located along the outer edge of condensed, partially aromatic systems in pyrrolic and pyridinic functional groups (corresponding to N-6 and N-5 sub-peaks; Fig. 7a-d). With increasing metamorphic grade, the percentage of $\mathrm{N}_{-} \mathrm{C}_{3}$ strongly increases (N-Q1 sub-peak; Fig. 7e, f; Fig. 9c, d). 


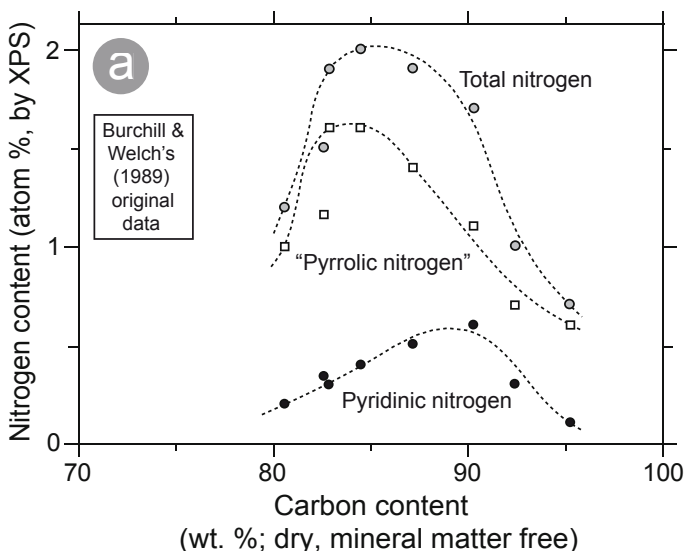

(wt. \%; dry, mineral matter free)

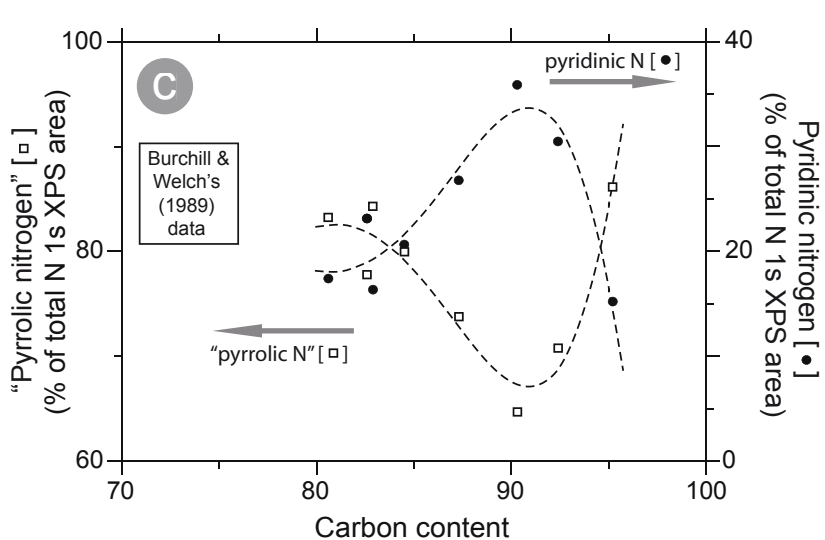

(wt. \%; dry, mineral matter free)

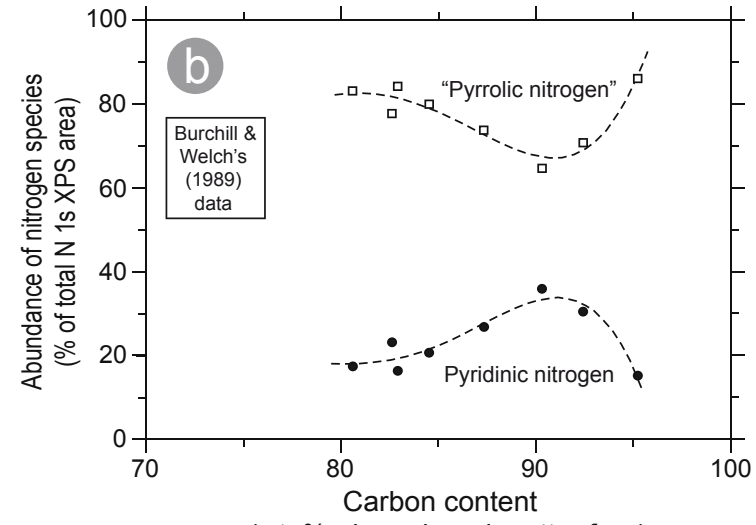

(wt. \%; dry, mineral matter free)

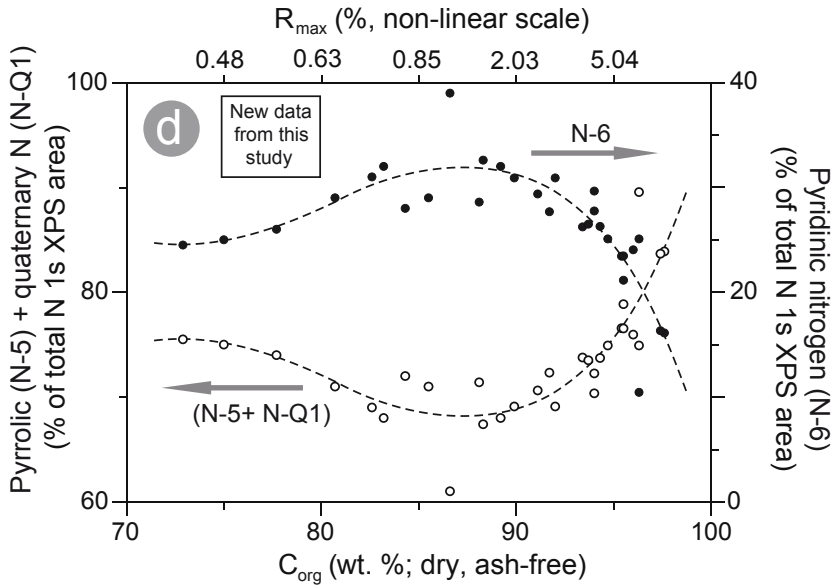

Fig. 11. Comparison of this study's nitrogen XPS data with data from Burchill and Welch (1989). (a) Re-drafted data with original trend lines from Burchill and Welch's (1989) original Figure 3, where N 1s XPS-quantified relative abundances of total, pyridinic, and "pyrrolic" nitrogen are plotted against the carbon content on a "dry, mineral matter free' (dmmf) basis. The same XPS data for "pyrrolic" and pyridinic nitrogen are expressed in terms of relative abundances (\% of the total XPS signal) along one common Y-axis (b) and using two separately scaled Y-axes for visualization of "mirror trends" (c), with newly assigned trend lines. (d) This study's new data on coals with increasing organic carbon content (i.e., with increasing thermal maturity, $\mathrm{R}_{\max }$ in \%) indicate that Burchill and Welch's (1989) so-called "pyrrolic" nitrogen actually represents a combination of the XPS subpeaks N-5 (pyrrolic, pyridonic, and other nitrogen species) and N-Q1 $\left(\mathrm{N}-\mathrm{C}_{3}\right)$. The trend line of the $(\mathrm{N}-5+\mathrm{N}-\mathrm{Q} 1)$ summary peak area approximates the mirror image of the trend line for pyridinic nitrogen N-6. Graph (d) is directly comparable to Burchill and Welch's (1989) data shown in (c) because 'carbon weight \% on a dry, mineral matter free basis' closely approximates the total organic carbon content on a dry, ash free (daf) basis in coals. Lines are drawn to guide the eye.

The strong increase of $\mathrm{N}-\mathrm{C}_{3}$ during natural low-grade metamorphism from anthracite to semi-graphite occurs at the expense of pyridinic and pyrrolic/pyridonic nitrogen (Fig. 7). Our observations need to be reconciled with Burchill and Welch's (1989) pioneering N 1s XPS study of coals from the British Isles where a figure (re-drawn here as Fig. 11a) depicts contrasting trends of XPS sub-peak abundances of only two species, namely pyridinic and "pyrrolic" nitrogen. The authors combined pyrrolic and $\mathrm{N}_{-} \mathrm{C}_{3}$ sub-peaks into a so-called "pyrrolic" peak and arrived at the perception that "pyrrolic" nitrogen reached its absolute maximum at $\sim 84$ wt. $\% \mathrm{C}$, whereas pyridinic nitrogen continued to increase in relative abundance into higher maturity until $\sim 90 \mathrm{wt} . \% \mathrm{C}$. They concluded that "pyrrolic" nitrogen was predominant, although the fraction of pyridinic nitrogen increased with rank and seemed to be more stable during later stages of coalification. However, by normalizing Burchill and Welch's (1989) "pyrrolic" and pyridinic XPS areas to the total N 1s XPS area (Fig. 11b), a Ushaped "pyrrolic" nitrogen curve becomes apparent with increasing concentrations along 
anthracitization, in contrast to the pattern of decreasing values for pyrrolic (N-5) alone (Fig. 7c). Our new data plotted in the same fashion (Fig. 11d) express a similar pattern as in Fig. 7c and thus indicate that Burchill and Welch's (1989) so-called "pyrrolic" nitrogen actually represents a combination of the XPS sub-peaks N-5 and N-Q1 $\left(\mathrm{N}-\mathrm{C}_{3}\right)$. The trend line of the $(\mathrm{N}-5+\mathrm{N}-\mathrm{Q} 1)$ summary peak area approximates the mirror image of the trend line for pyridinic nitrogen $\mathrm{N}-6$. We conclude that separate integrations of Burchill and Welch's (1989) N-5 and N-Q1 sub-peaks bring their data into agreement with ours suggesting that similar trends as those described in this study can be found independently in other sample series. Kelemen et al. $(1994,2006)$ have shown that the pre-metamorphic increase in the relative abundance of pyridinic nitrogen may be due to transformations of amide, amine and protonated pyridinic structures (i.e., quaternary nitrogen) during peat, lignite and subsequent bituminous coal stages. Overall, the presented evidence points toward universal trends in $\mathrm{N}_{\text {org }}$ speciation with increasing rank along a continuous introduction of $\mathrm{N}$ atoms into condensed ring systems as $\mathrm{N}-\mathrm{C}_{3}$, at the expense of edge-located $\mathrm{N}$.

Assuming that the formation of $\mathrm{N}_{-} \mathrm{C}_{3}$ is controlled kinetically, one can expect that this nitrogen species accumulates slowly rather than appearing suddenly as a result of a "maturation jump" at the onset of anthracitization. We propose a continuous pre-metamorphic increase in $\mathrm{N}_{-} \mathrm{C}_{3}(\mathrm{~N}-\mathrm{Q} 1)$ that is expressed as a dashed line in Fig. 9c for low-temperature maturation. Our hypothesis is supported by the fact that even in modern and immature sediments, small amounts of naturally occurring condensed aromatic ring structures can be found that have been linked to wildfires, anthropogenic contamination, and catalytic/enzymatic processes (e.g., Delfourne et al., 2000; Silliman et al., 2001; Finkelstein et al., 2006; Hockaday et al., 2007). It is likely that some of these condensed ring systems contain covalently bonded nitrogen. Nitrogen-containing and partially aromatic compounds may also form spontaneously in humic compounds at low temperature (Thorn and Mikita, 1992; Kraus et al., 2004; Hsu and Hatcher, 2005) or may have a catalytic origin (Jokic et al., 2004). Several studies report the occurrence of nitrogen-containing aromatic systems in brown coals (Imuta and Ouchi, 1973; Chaffee and Johns, 1983; Chaffee et al., 1984; Murata et al., 2001; Kashimura et al., 2004). We expect that these nitrogen species were produced by aromatization of inherited or neoformed condensed polycyclic compounds (e.g., terpenoids, steroids, hopanoids, alkaloids; Hayatsu et al., 1987) and could secondarily react with organic nitrogen and/or ammonia, nitrogen oxides and nitrates.

Aromatization of isolated polycyclic structures and condensation of aromatic units result in growth of small aromatic clusters throughout catagenesis, as suggested by modeling (e.g., Béhar and Vandenbroucke, 1987) and demonstrated by high resolution transmission electron microscopy (Neidhardt et al., 2004). The increase in the abundance of $\mathrm{N}-\mathrm{C}_{3}(\mathrm{~N}-\mathrm{Q} 1)$ during early metamorphism in relative terms (Fig. 7e, f) and in absolute terms (Fig. 9c, d) can be explained by a combination of (i) selective preservation of thermally stable 'core' nitrogen inside aromatic carbon lattices, and (ii) neoformation of $\mathrm{N}-\mathrm{C}_{3}$ in condensed ring systems while edge-located pyrrolic and pyridinic nitrogen would become progressively sparse due to structural rearrangement and chemical elimination. The steep metamorphic decline of pyridinic nitrogen (N-6; Fig. 7a, b) could be due to the tendency of aromatic rings to condense and form small polyaromatic clusters. In contrast, the comparatively more delayed metamorphic decrease of pyrrolic/pyridone nitrogen (N-5; Fig. 7c, d) may be explained by (i) a conversion of pyridone to pyrrole (Brent et al., 1970; Schmiers et al., 1999), and (ii) by the difficulty of expanding pyrrole-type rings to pyridine-type rings as suitable building blocks for accreting graphitic structures. Few nitrogen concentration data have been published for natural graphite (van Zuilen et al., 2005). Ader et al. (2006) assessed the loss of nitrogen from 
around thousand ppm in semi-graphites to few $\mathrm{ppm}$ in disordered-graphites. We therefore propose that the $\mathrm{N}_{-} \mathrm{C}_{3}$ content increases to reach an intermittent maximum during anthracitization, followed by a final decline towards well-ordered graphite with negligible concentrations of heteroelements associated with crystal lattice defects (Fig. 9c, d).

\subsection{The role of $\mathrm{H}$, $\mathrm{O}$-containing hot fluids during transformation of organic nitrogen}

Experimental dry, open-system programmed pyrolysis of model substances shows that pyridinic, pyrrolic and $\mathrm{N}_{-} \mathrm{C}_{3}$-type nitrogen species are remarkably stable at high temperature (e.g., Stanczyk and Boudou, 1994; Schmiers et al., 1999; Xiao et al., 2005; Boudou et al., 2006). Modelling with Optkin or 2D Petromod software, for example, justifies the early pyrolytic elimination of only a minor amount of anthracitic $\mathrm{N}_{\text {org }}$, even under high heat flow of up to $80 \mathrm{~W} / \mathrm{cm}^{2}$ from the Carboniferous to present time (Littke et al., 1995), in reality most $\mathrm{N}_{\text {org }}$ is not eliminated throughout low grade metamorphism (Boudou and Espitalié, 1995). In the laboratory under dry conditions, most $\mathrm{N}_{\text {org }}$ can only be decomposed at unnaturally high temperatures (Everlien, 1996). XPS data of solid pyrolysis residues indicate that programmed pyrolysis in the laboratory can reproduce some trends in naturally metamorphosed samples (Fig. 7), for example a decrease in the relative abundance of pyrrolic nitrogen and an increase in the relative abundance of quaternary $\mathrm{N}-\mathrm{C}_{3}$ nitrogen, especially when kerogen type III is used as a starting material (Kelemen et al., 1998, 1999). Important differences remain between artificial and natural paths of chemical evolution:

(i) Atomic N/C ratios of pyrolysis residues from coals in the laboratory are systematically larger than those found in naturally heated coals, in agreement with kinetic modelling predictions of thermal $\mathrm{N}_{\text {org }}$ stability in anthracite in the temperature range of natural anthracitization (e.g., Boudou and Espitalié, 1995).

(ii) During gradual heating in the laboratory, pyridinic nitrogen experiences only a slight decrease at higher temperatures. In contrast, natural chemical evolution of $\mathrm{N}_{\text {org }}$ causes significant losses of both pyrrolic and pyridinic nitrogen simultaneously with an exponential relative increase in $\mathrm{C}-\mathrm{N}_{3}$.

(iii) Laboratory thermal decomposition of organic matter isotopically disproportionates $\mathrm{N}_{\text {org }}$ and causes ${ }^{15} \mathrm{~N}$-enrichment in the residue (e.g., Stiehl and Lehmann, 1980). This study provides evidence that natural chemical evolution of $\mathrm{N}_{\text {org }}$ in type III kerogen causes no significant isotope fractionation in remaining $\mathrm{N}_{\text {org }}$ (Fig. 4).

A key distinction between natural and artificial paths of $\mathrm{N}_{\text {org }}$ chemical evolution is the availability of hot water during maturation. Laboratory pyrolysis experiments at high temperatures are typically performed in the absence of water, for example in a flow of inert gas at ambient pressure (e.g., Littke et al., 1995; Boudou and Espitalié, 1995; Kelemen et al., 1998, 1999). In contrast, deep sedimentary environments provide ubiquitous and abundant hot $\mathrm{H}$, O-containing formation fluids at considerable pressure. In the Pennsylvanian anthracite field, hydrothermal convecting fluids induced by Alleghanian uplift significantly increased (Daniels, 1992; Harrison et al., 2004). On local to regional scales, igneous intrusions can induce hydrothermal activity in porous host rocks with important repercussions on organic maturation below $725^{\circ} \mathrm{C}$ (Galushkin, 1997).

Therefore, we propose that naturally occurring loss of $\mathrm{N}_{\text {org }}$ is not simply due to thermal elimination reactions within organic matter (as is the case during dry heating in the laboratory), but that nature primarily relies on chemical reactions between organic matter and hot $\mathrm{H}$, O-containing fluids causing the gradual conversion of $\mathrm{N}_{\text {org }}$ to inorganic nitrogen 
species. The anthracite fields of Pennsylvania have been studied as a model for coal metamorphism (Hower and Gayer, 2002). Their paleotemperatures range from nearly $200{ }^{\circ} \mathrm{C}$ in semi-anthracites (Nickelsen, 1983; Levine, 1983) to $260-275^{\circ} \mathrm{C}$ for higher rank coals (Juster et al., 1987; Daniels and Altaner, 1990; Daniels et al., 1990). Our samples from this region were exposed to, and reacted with hot fluids during anthracitization.

At relatively low temperatures of 225 to $365^{\circ} \mathrm{C}$, hydrous pyrolysis experiments of an oil shale across the oil window to incipient gas generation (Lewan, 1985) released significant amounts of aqueous $\mathrm{NH}_{4}{ }^{+}$by decomposition of $\mathrm{N}_{\text {org }}$ (Barth et al., 1996). Ammonia formation was found to be slow at relatively low temperatures during hydrous pyrolysis of sedimentary organic matter, but accelerated above a temperature threshold corresponding to natural anthracitization (You and Gieskes, 2001). Everlien (1997) and Gerling et al. (1997) perfomed hydrous pyrolysis experiments at $370{ }^{\circ} \mathrm{C}$ (just below the $374{ }^{\circ} \mathrm{C}$ supercritical temperature of water at $22.1 \mathrm{MPa}$ ) on Westphalian coals with different maturities to simulate the genesis of molecular nitrogen in the North German Basin. They observed larger $\mathrm{N}_{2}$ yields and higher $\delta^{15} \mathrm{~N}_{\mathrm{N} 2}$ values with increasing coal rank, in agreement with $\delta^{15} \mathrm{~N}_{\mathrm{N} 2}$ values from elemental nitrogen in natural NW German gases (Boigk et al., 1976). Our estimate of the coals' $\mathrm{N}_{\text {org }}$ content and Gerling et al.'s (1997) $\mathrm{N}_{2}$ yields suggest that $\sim 0.5 \%$ of the initial $\mathrm{N}_{\text {org }}$ from coal with $\mathrm{R}_{\max } \sim 1 \%$ (C daf 85 wt. \%) had been converted to $\mathrm{N}_{2}$. Only $5 \%$ of the initial $\mathrm{N}_{\text {org }}$ from more mature coal with $\mathrm{R}_{\max } \sim 5.5 \%$ (C daf 95 wt. \%) had been converted to $\mathrm{N}_{2}$. These experimental low $\mathrm{N}_{2}$ yields during artificial heating of coals cannot explain the strong loss of $\mathrm{N}_{\text {org }}$ during natural anthracitization. Instead, they indirectly support other experimental evidence for ammonia being the main inorganic nitrogen product from hydrous pyrolysis of kerogen and model compounds (Ader et al., 1998a, b, 2000), as well as of other nitrogen heterocyles (Houser et al., 1986, 1989; Katritzky et al., 1995, 1997; Ogunsola, 2000; Yuan et al., 2006).

Artificial heating experiments at $460-600{ }^{\circ} \mathrm{C}$ and a pressure of $0.2 \mathrm{GPa}$ for 7 days in sealed gold cells used mixtures of (i) Pennsylvanian semi-anthracite and kaolinite (acting as water source and scavenger for ammonia) and Pennsylvanian semi-anthracite and (ii) model semi-anthracite-kaolinite such as carbazole-kaolinite mixtures (Ader et al., 1998a, b, 2000). These experiments produced ammonium-illite containing residual solids with $\delta^{15} \mathrm{~N}_{\text {org }}$ and $\delta^{15} \mathrm{~N}_{\mathrm{NH} 4}$ values that are similar to those observed in the organic and mineral matrix of natural meta-anthracites. The experiments also demonstrated that heating in the presence of water under pressure produced strong $\mathrm{N}_{\text {org }}$ losses and the formation of ammonia (ammonium-illite) of the same order of magnitude as observed during natural anthracitization. The observations are in agreement with earlier reports on the genesis of $\mathrm{NH}_{4}{ }^{+}$-bearing authigenic minerals in the Pennsylvanian anthracite field (Juster et al., 1987; Daniels and Altaner, 1990, 1993) and show that metamorphic fluids involved in $\mathrm{NH}_{4}{ }^{+}$-clay authigenesis can only be derived from an internal source, e.g. from alteration of the anthracite-clay assemblage (Daniels and Altaner, 1990, 1993).

Auxiliary information on the reactivity of $\mathrm{N}_{\text {org }}$ moieties is available from experimental studies on water-carbon reaction mechanisms at $\sim 800{ }^{\circ} \mathrm{C}$ and low pressure during carbon activation and gasification. In these conditions, water vapor appears to be more efficient in the elimination of $\mathrm{N}_{\text {org }}$ than other reagents, such as carbon dioxide (Boudou et al., 2006). Water vapor's high efficiency to eliminate $\mathrm{N}_{\text {org }}$ is more pronounced when the carbon matrix still offers a relatively high abundance of accessible and reactive nitrogen sites along the edges of small polyaromatic clusters (Rouzaud et al., 1991) at an early stage of anthracitization-graphitization. According to Kapteijn et al.'s model (1999), steam gasification chemically erodes reactive carbon structures/cycles that shield interior $\mathrm{N}-\mathrm{C}_{3}$. The 
resulting chemical exposure of formerly 'encapsulated' nitrogen atoms along exterior edges subsequently causes the elimination of $\mathrm{N}_{\text {org }}$ without discrimination among different nitrogen structural moieties.

Energy released from decay of naturally occurring radioactive isotopes in Earth's crust dissociates water molecules into energetic radicals that can form other reactive species, e.g. hydrogen and hydroxyl radicals, $\mathrm{H}_{2}, \mathrm{H}_{2} \mathrm{O}_{2}$, hydrous electrons ( $\mathrm{e}_{\mathrm{aq}}{ }^{-}$), and $\mathrm{H}^{-}$(Lin et al., 2005). Hydrogen radicals can also be produced by reaction of water with hydrocarbons and nitrogencontaining heterocycles (e.g., Townsend et al., 1988; Moriya and Enomoto, 2001; Yuan et al., 2006) and with fluids (e.g., via gas shift reaction; Sato et al., 2004). Aided by high temperatures, some of these highly reactive species may provide sufficiently large activation energies for abstracting structurally accessible organic nitrogen atoms from ultramicroporous carbonaceous matter during metamorphism. Alternatively, radiation from radioactivity can directly provide abundant activation energy. In the process of reaction with hydrogencontaining free radicals and water, $\mathrm{N}_{\text {org }}$ would be converted to $\mathrm{NH}_{3}$ and the small polyaromatic clusters would be locally oxidized and re-arranged. The impact of long-term, natural radiolysis on nitrogen compounds is demonstrated by the fact that $\mathrm{NH}_{4}{ }^{+}$in minerals is partly converted to elemental $\mathrm{N}_{2}$ (Grishina et al., 1998).

\subsection{Proposed model of progressive metamorphism of organic nitrogen}

Porosity in anthracite is significantly reduced as a result of nanometer-scale tectonic deformation (Ju et al., 2005), perhaps due to pressure-enhanced alignment and stacking of small polyaromatic clusters (Bustin et al., 1995). Ultramicropores with a diameter of $<0.4 \mathrm{~nm}$ (i.e., d002 interlayer spacing of the crystalline carbon structures) are already dominant in anthracites (Bratek et al., 2002) and gain importance with increasing rank and growth of graphitic-like structures (Lu et al., 2001). The porous texture of metamorphic carbonaceous matter from kerogens other than type III can be inferred from experimental carbonization of algal precursor materials which form large polyaromatic clusters followed by planar graphite during high-pressure breaking of pore walls (Oberlin, 1984).

The flow of heated water likely occurs through cleats (i.e., small fractures in coal) and interconnected open pores. On a smaller scale, an ultramicoporous matrix of mostly closed pores essentially consists of interconnected small polyaromatic clusters where heteroatoms are predominantly located along edges. Although individual water molecules measure only $\sim 0.28 \mathrm{~nm}$ in diameter and can be adsorbed between graphite layers (e.g., Ruuska and Pakkanen, 2003), water does not easily penetrate the interlayer spacing of crystalline carbon structures into $<0.4 \mathrm{~nm}$ diameter ultramicropores in high-rank coal, possibly due to individual water molecules' inability to maintain liquidity (Prinz and Littke, 2005). At the same time, the mobility of water within the carbonaceous ultramicoporous matrix is reduced by increasing surface hydrophobicity resulting from heteroatom removal and aromatization, although hydration of the exterior carbon surface of carbonaceous grains is facilitated by oxidation (e.g., Lerf et al., 2006), and the reduced polarity and viscosity of water at elevated temperatures facilitate the access of water to the carbonaceous matrix (Molina-Sabio et al., 2006). The solvent properties of liquid water at high temperature are similar to those of polar organic solvents at room temperature, thus favoring ionic versus free radical reactions with organic compounds. Supercritical water is especially reactive as a catalyst and reactant in high-temperature organic geochemistry (Siskin and Katritzky, 2000). We hypothesize that, in spite of rising temperature with increasing metamorphic grade, the rate of elimination of $\mathrm{N}_{\text {org }}$ would decrease exponentially, unless tectonic deformation and fracturing of anthracites provide new conduits for circulation and access of fluids (Cao et al., 2000). 
Our proposed concept of progressive $\mathrm{N}_{\text {org }}$ transformation and loss with increasing rank explains why $\mathrm{N}_{\text {org }}$ is strongly depleted during metamorphism while its isotopic composition remains essentially unchanged (Fig. 10). $\mathrm{N}_{\text {org }}$ is not subject to purely thermal isotropic elimination which would produce a Rayleigh-type isotopic fractionation. Instead, $\mathrm{N}_{\text {org }}$ is removed from the periphery of carbonacous particles along a progressing reaction front while the unreacted core retains $\mathrm{N}_{\text {org }}$ and its $\delta^{15} \mathrm{~N}_{\text {org }}$ value. The reacted peripheral zone of the carbonaceous matrix loses essentially all $\mathrm{N}_{\text {org }}$ (Ader et al., 2006), therefore the core's $\mathrm{N}_{\text {org }}$ and its $\delta^{15} \mathrm{~N}_{\text {org }}$ represent bulk nitrogen of the carbonaceous matrix.

Changes in the overall chemical speciation of $\mathrm{N}_{\text {org }}$ in anthracite and graphite simultaneously occur in two fundamental ways. First, hot $\mathrm{H}$, O-containing fluids or some of their components penetrate into the dense, poorly permeable, ultramicroporous carbonaceous matrix and eliminate $\mathrm{N}_{\text {org }}$ in the form of $\mathrm{NH}_{3}$ and $\mathrm{N}_{2}$ along the reaction front. Hot fluids are the likely source of energetic chemical reactants (e.g., $\mathrm{H}_{2}$, hydrogen and hydroxyl radicals) for $\mathrm{N}_{\text {org }}$ elimination. The supply of fluids to coal or other rocks containing organic material may derive from external formation fluids and from internal sources, e.g. from phyllosilicates, or via elimination of organic fuctional groups that generate new $\mathrm{H}_{2} \mathrm{O}$. The slow penetration of $\mathrm{H}$, O-containing fluids or some of their components into an increasingly hydrophobic and ultramicroporous carbonaceous matrix, and the outward diffusion of products $\left(\mathrm{NH}_{3}, \mathrm{CO}_{2}, \mathrm{~N}_{2}\right.$, etc.) limit the progress of the reaction front. Second, before the reaction front can reach $\mathrm{N}_{\text {org }}$ in the unreacted core of the carbonaceous matrix, core $\mathrm{N}_{\text {org }}$ is subject to purely thermal transformation, whereby this 'encapsulated' $\mathrm{N}_{\text {org }}$ stabilizes in the form of $\mathrm{N}_{-} \mathrm{C}_{3}$ nitrogen substituting for carbon in graphite-like structural domains with delocalized $\pi$-electron systems. Thus, the residual $\mathrm{N}_{\text {org }}$ in the unreacted core is preserved without significant isotope fractionation.

\section{CONCLUSIONS}

Multidisciplinary evidence from X-Ray Photoelectron Spectroscopy, nitrogen stable isotopes, traditional quantitative coal analyses, and other analytical approaches provide insight into the mechanisms and chemical consequences of low-grade metamorphism of organic nitrogen.

At the onset of metamorphism with a vitrinite reflectance $\mathrm{R}_{\max } \sim 2 \%$, organic nitrogen is dominantly present as pyrrolic and pyridinic nitrogen.

The relative abundance of isolated organic nitrogen $\mathrm{N}-\mathrm{C}_{3}$ atoms that are bonded covalently to three carbon atoms in condensed, partially aromatic ring systems increases during metamorphism. The occurrence of $\mathrm{N}_{-} \mathrm{C}_{3}$ (i.e., nitrogen atoms substituting for "graphitic" carbon in natural metamorphic organic matter) in natural metamorphic carbonaceous matter is documented here for the first time.

There is no evidence for systematic ${ }^{15} \mathrm{~N}$-enrichment with increasing rank in naturally matured samples. The apparent absence of Rayleigh-type nitrogen isotopic fractionation suggests that direct thermal loss of nitrogen from an organic matrix in an isotropic fashion does not serve as a major pathway for organic nitrogen elimination.

Pyridinic, pyrrolic and $\mathrm{N}-\mathrm{C}_{3}$ nitrogen in anthracite and semi-graphite is relatively stable during dry experimental heating in the laboratory, but can be eliminated at much lower temperature during wet experimental heating in the presence of sub- or supercritical water. This suggests that the chemical elimination of organic nitrogen during metamorphism is facilitated by hot $\mathrm{H}$, O-containing fluids. 
We propose that hot $\mathrm{H}$, O-containing fluids or some of their components gradually penetrate into the dense, ultramicroporous carbonaceous matrix and eliminate organic nitrogen along a progressing reaction front. Organic nitrogen is essentially eliminated from the reacted periphery of the carbonaceous matrix. Organic nitrogen in the unreacted core represents the bulk organic nitrogen of the entire carbonaceous matrix and preserves a conservative nitrogen isotope ratio, although the overall nitrogen concentration in the carbonaceous matrix decreases. Before the reaction front can reach the center of the carbonaceous matrix, an increasing part of core organic nitrogen chemically stabilizes as N$\mathrm{C}_{3}$. Thus, this nitrogen species becomes the dominant form of organic nitrogen at higher metamorphic grade.

Acknowledgments We are indebted to many expert colleagues for sharing their valuable samples and offering inspiration. Eric Daniels, ChevronTexaco Energy Research \& Technology Company, Richmond, California (http://www.clays.org/AskTheClayScientist/Eric\%20Daniels.html), and Jeffrey Levine, Consultant Geologist, Dallas (http://www.levineonline.com/jeffrey/index.asp), provided Pennsylvanian anthracites. We gratefully acknowledge Angelika Vieth's (Geologischer Dienst Nordrhein-Westfalen, Krefeld, Germany, http://www.gd.nrw.de/home.php) contribution of samples from the Bramscher Massiv, and Peter Gerling's (Bundesanstalt für Geowissenschaften und Rohstoffe Geozentrum Hannover, http://www.bgr.bund.del) coal samples from Northern Germany. We thank Mohamed Chehimi and Carol Bilem for technical assistance with some XPS analyses at ITODYS, University of Paris VII (France). Our manuscript benefited greatly from the constructive criticism of Jay Brandes, JoAnn Holloway, Iain Pitcairn, and an anonymous reviewer. This work was supported by a grant from Chevron Petroleum Technology Company to J. P. B., and by U.S. Department of Energy, Basic Energy Research Grant number DEFG02-00ER15032 to A. S. and M. M.

\section{REFERENCES}

Ader M., Boudou J.-P., Javoy M., Goffé B., and Daniels E. (1998a) Isotope study on organic nitrogen of Westphalian anthracites from the Western Middle field of Pennsylvania (U.S.A.) and from the Bramsche Massif (Germany). Org. Geochem. 29, 315-323.

Ader M., Boudou J.-P., Roux J., Daniels E., and Javoy M. (2000) Nitrogen isotopic composition of fixed ammonium in rocks: Evidence for a possible ammonia stability in fluids? Goldschmidt 2000 J. Conf. Abstr. 5, 117-118.

Ader M., Cartigny P., Boudou J.-P., Petit E., Oh J. H., and Javoy M. (2006) Nitrogen isotopic evolution of carbonaceous matter during metamorphism: Methodology and preliminary results. Chem. Geol. 232, 152-169.

Ader M., Javoy M., Boudou J.-P., Hieronimus B., Roux J., and Daniels E. (1998b) Nitrogen isotopic composition of ammonium-rich illite in anthracites and organic-rich shales from eastern Pennsylvania. Min. Mag. 62A, 13.

Andersen T., Austrheim H., Burke E. A. J., and Elvevold S. (1993) $\mathrm{N}_{2}$ and $\mathrm{CO}_{2}$ in deep crustal fluids: evidence from the Caledonides of Norway. Chem. Geol. 108, 113-132.

Babich I. V., Seshan K., and Lefferts L. (2005) Nature of nitrogen specie in coke and their role in $\mathrm{NO}_{\mathrm{x}}$ formation during FCC catalyst regeneration. Appl. Catal. B-Environ. 59, 205-211.

Barker C. E., Bone Y., and Lewan M. D. (1998) Fluid inclusion and vitrinite reflectance geothermometry compared to heat-flow models of maximum paleotemperature next to dikes, western onshore Gippsland Basin, Australia. Int. J. Coal Geol. 37, 73-111. 
Barth T., Rist K., Huseby B., and Ocampo R. (1996) The distribution of nitrogen between bitumen, water and residue in hydrous pyrolysis of extracted Messel oil shale. Org. Geochem. 24, 889-895.

Béhar F., and Vandenbroucke M. (1987) Chemical modelling of kerogens. Org. Geochem. 11, $15-24$.

Bennett B., Chen M., Brincat D., Gelin F. J. P., and Larter S. R. (2002) Fractionation of benzocarbazoles between source rocks and petroleums. Org. Geochem. 33, 545-559.

Berner R. A. (2006) Geological nitrogen cycle and atmospheric $\mathrm{N}_{2}$ over Phanerozoic time. Geology 34, 413-415.

Beyssac O., Rouzaud J.-N., Goffé B., Brunet F., and Chopin C. (2002) Graphitization in a high pressure low-temperature metamorphic gradient: A Raman microspectroscopy and HRTEM study. Contrib. Mineral. Petrol. 143, 19-31.

Blom L., Edelhausen L., and van Krevelen D. W. (1957) Chemical structure and properties of coal. XVIII. Oxygen groups in coal and related products. Fuel 36, 135-153.

Boigk H., Hagemann H. W., Stahl, W., and Wollanke G. (1976) Isotopenphysikalische Untersuchungen zur Herkunft und Migration des Stickstoffs nordwestdeutscher Erdgase aus Oberkarbon und Rotliegend. Erdöl Kohle Erdgas Petrochem. 29, 103112.

Boudou J.-P., and Espitalié J. (1995) Molecular nitrogen from coal pyrolysis: Kinetic modelling. Chem. Geol. 126, 319-333.

Boudou J.-P., Mariotti A., and Oudin J. L. (1984a) Unexpected enrichment of nitrogen during the diagenetic evolution of sedimentary organic matter. Fuel 63, 1508-1510.

Boudou J.-P., Parent Ph., Suarez-Garcia F., Villar-Rodil S., Martinez-Alonso A., and Tascon J. M. D. (2006) Nitrogen in aramid-based activated carbon fibers by TPD, XPS and XANES. Carbon 44, 2452-2462.

Boudou J.-P., Pelet R., and Letolle R. (1984b) A model of the diagenetic evolution of coaly sedimentary organic matter. Geochim. Cosmochim. Acta 48, 1357-1362.

Boutique J. P., Verbist J. J., Fripiat J. G., Delhalle J., Pfister-Guillouzo G., and Ashwell G. J. (1984) 3,5,11,13-tetraazacycl[3.3.3]azine: Theoretical (ab initio) and experimental (Xray and ultraviolet photoelectron spectroscopy) studies of the electronic structure. $J$. Am. Chem. Soc. 106, 4374-4378.

Bratek K., Bratek W., Gerus-Piasecka I., Jasieńko S., and Wilk P. (2002) Properties and structure of different rank anthracites. Fuel 81, 97-108.

Brent D. A., Hribar J. D., and DeJongh D. C. (1970) Pyrolysis of 2-pyrone, coumarin, and 2pyridone. J. Org. Chem. 35, 135-137.

Buckley A. N., Kelly M. D., Nelson P. F., and Riley K. W. (1995) Inorganic nitrogen in Australian semi-anthracites; implications for determining organic nitrogen functionality in bituminous coals by X-ray photoelectron spectroscopy. Fuel Process. Technol. 43, 47-60.

Buckley A. N., Riley K. W., and Wilson M. A. (1996) Heteroatom functionality in a high-sulfur Chinese bituminous coal. Org. Geochem. 24, 389-392. 
Burchill P., and Welch L. S. (1989) Variation of nitrogen content and functionality with rank for some UK bituminous coals. Fuel 68, 100-104.

Bustin R. M., Ross J. V., and Rouzaud J.-N. (1995) Mechanisms of graphite formation from kerogen: Experimental 1evidence. Int. J. Coal Geol. 28, 1-36.

Cao Y., Mitchell G. D., Davis A., and Wang D. (2000) Deformation metamorphism of bituminous and anthracite coals from China. Int. J. Coal Geol. 43, 227-242.

Casanovas J., Ricart J. M., Rubio J., Illas F., and Jimenez-Mateos J. M. (1996) Origin of the large $\mathrm{N} 1 \mathrm{~s}$ binding energy in X-ray photoelectron spectra of calcined carbonaceous materials. J. Am. Chem. Soc. 118, 8071-8076.

Chaffee A. L., and Johns R. B. (1983) Polycyclic aromatic hydrocarbons in Australian coals. I. Angularly fused pentacyclic tri- and tetraaromatic components of Victorian brown coal. Geochim. Cosmochim. Acta 47, 2141-2155.

Chaffee A. L., Strachan M. G., and Johns R. B. (1984) Polycyclic aromatic hydrocarbons in Australian coals. II. Novel tetracyclic components from Victorian brown coal. Geochim. Cosmochim. Acta 48, 2037-2043.

Choi H. C., Park J., and Kim B. (2005) Distribution and structure of $\mathrm{N}$ atoms in multiwalled carbon nanotubes using variable-energy X-ray photoelectron spectroscopy. J. Phys. Chem. B 109, 4333-4340.

Clark D. T., Peeling J. and Colling L. (1976) An experimental and theoretical investigation of the core level spectra of a series of amino acids, dipeptides and polypeptides. BBAProtein. Struct. M. 453, 533-545.

Daniels E. J. (1992) Nature and origin of minerals in anthracite from eastern Pennsylvania. Ph. D. thesis, Illinois Univ.

Daniels E. J., and Altaner S. P. (1990) Clay mineral authigenesis in coal and shale from the Anthracite region, Pennsylvania. Am. Mineral. 75, 825-839.

Daniels E. J., and Altaner S. P. (1993) Inorganic nitrogen in anthracite from eastern Pennsylvania, USA. Int. J. Coal Geol. 22, 21-35.

Daniels E. J., Altaner S. P., Marshak S., and Eggleston J. R. (1990) Hydrothermal alteration in anthracite from eastern Pennsylvania: Implications for mechanisms of anthracite formation. Geology 18, 247-250.

Daulan C., Lyubchik S. B., Rouzaud J.-N., and Béguin F. (1998) Influence of anthracite pretreatment in the preparation of activated carbons. Fuel, 495-502.

Delfourne E., Bontemps-Subielos N., and Bastide J. (2000) Structure revision of the marine pentacyclic aromatic alkaloid: Cystodamine. Tetrahedron Lett. 41, 3863-3864.

Dos Santos M. C., and Alvarez F. (1998) Nitrogen substitution of carbon in graphite: Structure evolution toward molecular forms. Phys. Rev. B, Condens. Matter 58, 13918-13924.

Dumitrescu M., and Brassell S. C. (2006) Compositional and isotopic characteristics of organic matter for the early Aptian Oceanic Anoxic Event at Shatsky Rise, ODP Leg 198. Palaeogeogr. Palaeoclimatol. Palaeoecol. 235, 168-191.

Durand B., and Monin J. C. (1980) Elemental analysis of kerogens (C, H, O, N, S, Fe). In Kerogen (ed. B. Durand). Editions Technip, Paris. pp. 113-142. 
Durand B., and Nicaise G. (1980) Procedures for kerogen isolation. In Kerogen (ed. B. Durand). Editions Technip, Paris. pp 35-53.

Everlien G. (1996) High-temperature programmed pyrolysis of Paleozoic source rocks from Northern Germany and adjacent areas and its thermodynamic constraints. Org. Geochem. 24, 985-998.

Everlien G. (1997) Hydrous pyrolysis of high-maturity Paleozoic coals and black shales from Central Europe and adjacent areas - Thermodynamic considerations. Geol. Jahrbuch D 103, 43-64.

Finkelstein D. B., Pratt L. M., and Brassell S. C. (2006) Can biomass burning produce a globally significant carbon-isotope excursion in the sedimentary record? Earth Planet. Sci. Lett. 250, 501-510.

Frey M. (1986) Very low-grade metamorphism of the Alps - An introduction. Schweiz. Mineral. Petrogr. Mitt. 66, 13-27.

Frey M., and Robinson D. (1999) Low-Grade Metamorphism. Blackwell Science Ltd.

Fryer J. R. (1981) The micropore structure of disordered carbons determined by high resolution electron microscopy. Carbon 19, 431-439.

Galimov E. M. (1980) $\mathrm{C}^{13} / \mathrm{C}^{12}$ in kerogen. In Kerogen (ed. B. Durand), Editions Technip, Paris. pp. 271-300.

Galushkin Y. I. (1997) Thermal effects of igneous intrusions on maturity of organic matter: A possible mechanism of intrusion. Org. Geochem. 26, 645-658.

Gammon W. J., Kraft O., Reilly A. C., and Holloway B. C. (2003) Experimental comparison of $\mathrm{N}(1 \mathrm{~s})$ X-ray photoelectron spectroscopy binding energies of hard and elastic amorphous carbon nitride films with reference organic compounds. Carbon 41, 19171923.

Gerling P., Idiz E., Everlien G., and Sohns E. (1997) New aspects on the origin of nitrogen in natural gas in Northern Germany. Geol. Jahrbuch D 103, 65-85.

Gong B., Buckley A. N., Lamb R. N., and Nelson P. F. (1999) XPS determination of the forms of nitrogen in coal pyrolysis chars. Surf. Interface Anal. 28, 126-130.

Gong B., Pigram P. J., and Lamb R. N. (1997) Identification of inorganic nitrogen in an Australian bituminous coal using X-ray photoelectron spectroscopy (XPS) and timeof-flight secondary ion mass spectrometry (TOFSIMS). Int. J. Coal Geol. 34, 53-68.

Gretener P. E., and Curtis C. D. (1982) Role of temperature and time on organic metamorphism. AAPG Bull. 66, 1124-1149.

Grishina S., Pironon J., Mazurov M., Goryainov S., Pustilnikov A., Fon-der-Flaas G., and Guerci A. (1998) Organic inclusions in salt. Part 3. Oil and gas inclusions in Cambrian evaporite deposit from East Siberia. A contribution to the understanding of nitrogen generation in evaporites. Org. Geochem. 28, 297-310.

Guedes A., Noronha F., and Prieto A. C. (2005) Characterisation of dispersed organic matter from lower Palaeozoic metasedimentary rocks by organic petrography, X-ray diffraction and micro-Raman spectroscopy analyses. Int. J. Coal Geol. 62, 237-249.

Hallam M., and Eugster H. P. (1976) Ammonium silicate stability relations. Contrib. Mineral. Petrol. 57, 227-244. 
Harrison M. J., Marshak S., and Onasch C. M. (2004) Stratigraphic control of hot fluids on anthracitization, Lackawanna synclinorium, Pennsylvania. Tectonophysics 378, 85103.

Hasenmueller N. R., and Comer J. B. (2000) Compilation of gas potential of the New Albany Shale (GRI CD). Indiana Geological Survey Illinois Basin Consortium, IBS04, Indiana Geological Survey, Bloomington, Indiana.

Hayatsu R., Botto R. E., Scott R. G., McBeth R. L., and Winans R. E. (1987) Thermal catalytic transformation of pentacyclic triterpenoids: Alteration of geochemical fossils during coalification. Org. Geochem. 11, 245-250.

He H., Zhou Q., Frost R. L., Wood B. J., Duong L. V., and Kloprogge J. T. (2007) A X-ray photoelectron spectroscopy study of HDTMAB distribution within organoclays. Spectrochim. Acta A 66, 1180-1188.

Hellgren N., Johansson M. P., Brournan E., Hultman L., and Sundgren J.-E. (1999) Role of nitrogen in the formation of hard and elastic $\mathrm{CN}_{\mathrm{x}}$ thin films by reactive magnetron sputtering. Phys. Rev. B 59, 5162-5169.

Hockaday W. C., Grannas A. M., Kim S., and Hatcher P. G. (2007) The transformation and mobility of charcoal in a fire-impacted watershed. Geochim. Cosmochim. Acta, 71, 3432-3445.

Holloway J. A. M., and Dahlgren R. A. (2002) Nitrogen in rock: Occurrences and biogeochemical implications. Global Biogeochem. Cycles 16, 1118, doi:10.1029/2002GB001862

Houser T. J., Tiffany D. M., Li Z., McCarville M. E., and Houghton M. E. (1986) Reactivity of some organic compounds with supercritical water. Fuel 65, 827-832.

Houser T. J., Tsao C. C., Dyla J. E., Van Atten M. K., and McCarville M. E. (1989) The reactivity of tetrahydroquinoline, benzylamine and bibenzyl with supercritical water. Fuel 68, 323-327.

Hower J. C., and Gayer R. A. (2002) Mechanisms of coal metamorphism: Case studies from Paleozoic coalfields. Int. J. Coal Geol. 50, 215-245.

Hsu P. H., and Hatcher P. G. (2005) New evidence for covalent coupling of peptides to humic acids based on 2D NMR spectroscopy: A means for preservation. Geochim. Cosmochim. Acta 69, 4521-4533.

Imuta K., and Ouchi K. (1973) Isolation of adamantane from coal extract. Fuel 52, 301-302.

Isaacs L. G. (1970) The graphitization of organic compounds. III. Heterocyclic nitrogen derivatives of anthracene and phenanthrene. Carbon 8, 1-5.

Jia Y. (2006) Nitrogen isotope fractionations during progressive metamorphism: A case study from the Paleozoic Cooma metasedimentary complex, southeastern Australia. Geochim. Cosmochim Acta 70, 5201-5214.

Jokic A., Wang M. C., Liu C., Frenkel A. I., and Huang P. M. (2004) Integration of the polyphenol and Maillard reactions into a unified abiotic pathway for humification in nature: the role of $\delta-\mathrm{MnO}_{2}$. Org. Geochem. 35, 747-762. 
Ju Y., Jiang B., Hou Q., and Wang G. (2005) Relationship between nano-scale deformation of coal structure and metamorphic-deformed environments. Chin. Sci. Bull. 50, 17841795 .

Juster T. C., Brown P. E., and Bailey S. W. (1987) $\mathrm{NH}_{4}$-bearing illite in very low-grade metamorphic rocks associated with coal, northeastern Pennsylvania. Am. Mineral. 72 , $555-565$.

Kapteijn F., Moulijn J. A., Matzner S., and Boehm H.-P. (1999) The development of nitrogen functionality in model chars during gasification in $\mathrm{CO}_{2}$ and $\mathrm{O}_{2}$. Carbon 37, 11431150 .

Kashimura N., Hayashia J. I., Li C. Z., Sathe C., and Chiba T. (2004) Evidence of polycondensed aromatic rings in a Victorian brown coal. Fuel 83, 97-107.

Katritzky A. R., Ignatchenko E. S., Allin S. M., Siskin M., Ferrughelli D. L., and Rabai J. (1997) Aqueous high-temperature chemistry of carbo- and heterocycles. 30. Aquathermolysis of phenyl-substituted hydroxyquinolines Energy Fuelss 11, 174182.

Katritzky A. R., Shipkova P. A., Allin S. M., Barcock R. A., Siskin M., and Olmstead W. N. (1995) Aqueous high-temperature chemistry. 22. Nitrogen-containing heterocycles in supercritical water at $460{ }^{\circ} \mathrm{C}$. Energy Fuels 9, 580-589.

Kelemen S. R., Afeworki M., Gorbaty M. L., Kwiatek P. J., Sansone M., and Walters C. C. (2006) Thermal transformations of nitrogen and sulfur forms in peat related to coalification. Energy Fuels 20, 635-652.

Kelemen S. R., Freund H., Gorbaty M. L., and Kwiatek P. J. (1999) Thermal chemistry of nitrogen in kerogen and low-rank coal. Energy Fuels 13, 529-538.

Kelemen S. R., Gorbaty M. L., and Kwiatek P. J. (1994) Quantification of nitrogen forms in Argonne premium coals. Energy Fuels 8, 896-906.

Kelemen S. R., Gorbaty M. L., Kwiatek P. J., Fletcher T. H., Watt M., Solum M. S., and Pugmire R. J. (1998) Nitrogen transformation in coal during pyrolysis. Energy Fuels 12, 159-173.

Kraus T. E. C., Zasoski R. J., Dahlgren R. A., Horwath W. R., and Preston C. M. (2004) Carbon and nitrogen dynamics in a forest soil amended with purified tannins from different plant species. Soil Biol. Biochem. 36, 309-321.

Kwiecińska B., and Petersen H. I. (2004) Graphite, semi-graphite, natural coke, and natural char classification-ICCP system. Int. J. Coal Geol. 57, 99-116.

Lahaye J., Nanse G., Fioux P., Bagreev A., Broshnik A., and Strelko V. (1999) Chemical transformation during the carbonisation in air and the pyrolysis under argon of a vinylpyridine-divinylbenzene copolymer by X-ray photoelectron spectroscopy. Appl. Surf. Sci. 147, 153-174.

Leaver D. (1986) The synthesis and characterisation of cyclazines and related N-bridged annulenes. Pure Appl. Chem. 58, 143-152 (also available at: htt://www.iupac.org/publications/pac/1986/pdf/5801x0143.pdf ).

Lerf A., Buchsteiner A., Pieper J., Schöttl S., Dekany I., Szabo T., and Boehm H. P. (2006) Hydration behavior and dynamics of water molecules in graphite oxide. J. Phys. Chem. Solids 67, 1106-1110. 
Levine J. R. (1983) Tectonic history of coal-bearing sediments in eastern Pennsylvania using coal reflectance anisotropy. Ph.D. thesis, The Pennsylvania State Univ.

Lewan M. D. (1985) Evaluation of petroleum generation by hydrous pyrolysis. Phil. Trans. $R$. Soc. Lond. A 315, 123-134.

Lewan M. D. (1986) Stable carbon isotopes of amorphous kerogens from Phanerozoic sedimentary rocks. Geochim. Cosmochim. Acta 50, 1583-1591.

Lin L.-H., Hall J., Lippmann-Pipke J., Ward J. A., Sherwood Lollar B., DeFlaun M., Rothmel R., Moser D., Gihring T. M., Mislowack B., and Onstott T. C. (2005) Radiolytic $\mathrm{H}_{2}$ in continental crust: Nuclear power for deep subsurface microbial communities. Geochem. Geophys. Geosys. 6, Q07003, doi:10.1029/2004GC000907.

Lis G. P., Schimmelmann A., and Mastalerz M. (2006) D/H ratios and hydrogen exchangeability of type-II kerogens with increasing thermal maturity. Org. Geochem. 37, 342-353.

Littke R., Krooss B. M., Idiz E. F., and Frielingsdorf J. (1995) Molecular nitrogen in natural gas accumulations: Generation from sedimentary organic matter at high temperatures. AAPG Bull. 79, 410-430.

Liu Z.-H., Brown N. M. D., and McKinley A. (1997) Characterization of oxygen plasmamodified mica surfaces using XPS and AFM. Appl. Surf. Sci. 108, 319-332.

Lu L., Sahajwalla V., Kong C., and Harris D. (2001) Quantitative X-ray diffraction analysis and its application to various coals. Carbon 39, 1821-1833.

Mahajan O. P. (1984) Physical characterization of coal. Powder Technol. 40, 1-15.

Manning D. A. C., and Hutcheon I. E. (2004) Distribution and mineralogical controls on ammonium in deep groundwaters. Appl. Geochem. 19, 1495-1503.

Mastalerz M., Glikson M., Stankiewicz B. A., Volkova I. B., and Bustin R. M. (2000) Organic and mineral matter in a Precambrian shungite deposit from Karelia, Russia. In Organic Matter and Mineralisation: Thermal Alteration, Hydrocarbon Generation, and Role in Metallogenesis (eds. M. Glikson and M. Mastalerz). Kluwer Academic Publishers, Dordrecht. pp. 102-119.

Melezhik V. A., Fallick A. E., Filippov M. M., and Larsen O. (1999) Karelian shungite - an indication of 2.0-Ga-old metamorphosed oil-shale and generation of petroleum: geology, lithology and geochemistry. Earth Sci. Rev. 47, 1-40.

Meyers P. A. (2006) Paleoceanographic and paleoclimatic similarities between Mediterranean sapropels and Cretaceous black shales. Palaeogeogr. Palaeoclimatol. Palaeoecol. 235, 305-320.

Mitra-Kirtley S., Mullins O. C., Branthaver J. F., and Cramer S. P. (1993) Nitrogen chemistry of kerogens and bitumens from X-ray absorption near-edge structure spectroscopy. Energy Fuels 7, 1128-1134.

Molina-Sabio M., Sanchez-Montero M. J., Juarez-Galan J. M., Salvador F., RodriguezReinoso F., and Salvador A. (2006) Development of porosity in a char during reaction with steam or supercritical water. J. Phys. Chem. B 110, 12360-12364. 
Moriya T., and Enomoto H. (2001) Conversion of polyethylene to oil using supercritical water and donation of hydrogen in supercritical water. Kobunshi Ronbunshu 58, 661673.

Mullis J., Wolf M., and Mählmann R. F. (2003) Temperature determination between 50 and $270{ }^{\circ} \mathrm{C}$ through fluid inclusion microthermometry and vitrinite reflectance values in the external parts of the central Alps. Geophys. Res. Abstr. 5, 04334.

Murata S., Tani Y., Hiro M., Kidena K., Artok L., Nomura M., and Miyake M. (2001) Structural analysis of coal through RICO reaction: Detailed analysis of heavy fractions. Fuel 80, 2099-2109.

Neidhardt J., Hultman L., and Czigány Z. S. (2004) Correlated high resolution transmission electron microscopy and $\mathrm{X}$-ray photoelectron spectroscopy studies of structured $\mathrm{CNx}$ $(0<\mathrm{x}<0.25)$ thin solid films. Carbon 42, 2729-2734.

Nickelsen R. P. (1983) Ambient temperatures during the Alleghany Orogeny. In Silurian Depositional History and Alleghanian Deformation in the Pennsylvania Valley and Ridge (eds. R. P. Nickelsen and E. Cotter). Guidebook, 48th Annual Field Conference of Pennsylvania Geologists, Danville, College Station, Pennsylvania. pp. 64-66.

NIST XPS database: http://srdata.nist.gov/xps/main_search menu.htm.

Oberlin A. (1984) Carbonization and graphitization. Carbon 22, 521-541.

Ogunsola O. M. (2000) Decomposition of isoquinoline and quinoline by supercritical water. J. Hazard. Mater. 74, 187-195.

Oldenburg T. B. P., Larter S. R., and Huang H. (2007) Nitrogen isotope systematics of petroleum fractions of differing polarity - Neutral versus basic compounds Org. Geochem. 38, 1789-1794.

Paxton S. T. (1983) Relationships between Pennsylvanian-age lithic sandstone and mudrock diagenesis and coal rank in the Central Appalachians. Ph. D. thesis, Pennsylvania State Univ.

Pels J. R., Kapteijn F., Moulijn J. A., Zhu Q., and Thomas K. M. (1995) Evolution of nitrogen functionalities in carbonaceous materials during pyrolysis. Carbon 33, 1641-1653.

Petersen H. I. (2006) The petroleum generation potential and effective oil window of humic coals related to coal composition and age. Int. J. Coal Geol. 67, 221-248.

Pinti D. L., Hashizume K., and Matsuda J.-I. (2001) Nitrogen and argon signatures in 3.8 to $2.8 \mathrm{Ga}$ metasediments: Clues on the chemical state of the Archean ocean and the deep biosphere. Geochim. Cosmochim. Acta 65, 2301-2315

Pitcairn I. K., Teagle D. A. H., Kerrich R, Craw D., and Brewer T. S. (2005) The behavior of nitrogen and nitrogen isotopes during metamorphism and mineralization: Evidence from the Otago and Alpine Schists, New Zealand. Earth Planet. Sci. Lett. 233, 229246.

Price L. C., and DeWitt E. (2001) Evidence and characteristics of hydrolytic disproportionation of organic matter during metasomatic processes. Geochim. Cosmochim. Acta 65, 3791-3826.

Prinz D., and Littke R. (2005) Development of the micro- and ultramicroporous structure of coals with rank as deduced from the accessibility to water. Fuel 84, 1645-1652. 
Radlinski A. P., Mastalerz M., Hinde A. L., Hainbuchner M., Rauch H., Baron M., Lin J. S., Fan L., and Thiyagarajan P. (2004) Application of SAXS and SANS in evaluation of porosity, pore size distribution and surface area of coal. Int. J. Coal Geol. 59, 245-271.

Rau G. H., Arthur M. A., and Dean W. E. (1987) ${ }^{15} \mathrm{~N} /{ }^{14} \mathrm{~N}$ variations in Cretaceous Atlantic sedimentary sequences: Implication for past changes in marine nitrogen biogeochemistry. Earth Planet. Sci. Lett. 82, 269-279.

Reuther U., and Hirsch A. (2000) Synthesis, properties and chemistry of Aza[60]fullerene. Carbon 38, 1539-1549.

Rigby D., and Batts, B. D. (1986) The isotopic composition of nitrogen in Australian coals and oil shales. Chem. Geol. 58, 273-282.

Rimmer S. M., Rowe H. D., Taulbee D. N., and Hower J. C. (2006) Influence of maceral content on $\delta^{13} \mathrm{C}$ and $\delta^{15} \mathrm{~N}$ in a Middle Pennsylvanian coal. Chem. Geol. 225, 77-90.

Ripalda J. M., Galán L., and Montero I. (1998) An XPS study of carbon nitride synthesized by ion beam nitridation of $\mathrm{C}_{60}$ fullerene. Diamond Relat. Mater. 7, 402-406.

Robl T. L., Davis, B. H. (1993) Comparison of the HF-HCl and HF-BF3 maceration techniques and the chemistry of resultant organic concentrates. Org. Geochem. 20, 249-255.

Rouzaud J.-N., Duval B., and Leroy J. (1991) Coke microtexture: a key for coke reactivity. In Fundamental Issues in Control of Carbon Gasification Reactivity (eds. J. Lahaye and P. Ehrburger). Kluwer Academic Publisher. pp. 257-268.

Ruuska H., and Pakkanen T. A. (2003) Ab initio model study on a water molecule between graphite layers. Carbon 41, 699-706.

Sato T., Kurosawa S., Smith R. L., Adschiri T., and Arai K. (2004) Water gas shift reaction kinetics under noncatalytic conditions in supercritical water. J. Supercrit. Fluids, 29, 113-119.

Schimmelmann A., Lewan M. D., Wintsch, R.P. (1999) D/H isotope ratios of kerogen, oil, and water in hydrous pyrolysis of source rocks containing kerogen types I, II, IIS, and III. Geochim. Cosmochim. Acta 63, 3751-3766.

Schimmelmann A., Sessions A. L., and Mastalerz M. (2006) Hydrogen isotopic (D/H) composition of organic matter during diagenesis and thermal maturation. Ann. Rev. Earth Planet. Sci. 34, 501-533.

Schimmelmann A., Wintsch R. P., Lewan M. D., and DeNiro M. J. (1998) Chitin: 'Forgotten' source of nitrogen - From modern chitin to thermally mature kerogen: Lessons from nitrogen isotope ratios. In Nitrogen-Containing Macromolecules in the Biosphere and Geosphere (eds. B. A. Stankiewicz and P. F. van Bergen). American Chemical Society, Symp. Ser. 707. pp 226-242.

Schmiers H., Friebel J., Streubel P., Hesse R., and Köpsel R. (1999) Change of chemical bonding of nitrogen of polymeric N-heterocylcic compunds during pyrolysis. Carbon 37, 1965-1978.

Schmitter J. M., Ignatiadas I., and Arpino P. J. (1983) Distribution of diaromatic nitrogen bases in crude oils. Geochim. Cosmochim. Acta 47, 1975-1984. 
Schnadt J., O'Shea J. N., Patthey L., Schiessling J., Krempasky J., Shi M., Mårtensson N., and Brühwiler P. A. (2003) Structural study of adsorption of isonicotinic acid and related molecules on rutile $\mathrm{TiO}_{2}(110)$ II: XPS. Surf. Sci. 544, 74-86.

Schwab V., Spangenberg J. E., and Grimalt J. O. (2005) Chemical and carbon isotopic evolution of hydrocarbons during prograde metamorphism from $100{ }^{\circ} \mathrm{C}$ to $550{ }^{\circ} \mathrm{C}$ : Case study in the Liassic black shale formation of Central Swiss Alps. Geochim. Cosmochim. Acta 69, 1825-1840.

Silliman J. E., Meyers P. A., Eadie B. J., and Val Klump J. (2001) A hypothesis for the origin of perylene based on its low abundance in sediments of Green Bay, Wisconsin. Chem. Geol. 177, 309-322.

Simoneit B. R. T., Schones H. K., Haug P., and Burlingame A. L. (1971) High resolution mass spectrometry of nitrogenous compounds of the Colorado Green River formation oil shale. Chem. Geol. 7, 123-141.

Siskin M., and Katritzky A. R. (2000) A review of the reactivity of organic compounds with oxygen-containing functionality in superheated water. J. Anal. Appl. Pyrol. 54, 193214.

Sjöström H., Stafström S., Boman M., and Sundgren J.-E. (1995) Superhard and elastic carbon nitride thin films having fullerenelike microstructure. Phys. Rev. Lett. 75, $1336-$

Stach E., Mackowsky M. T., Teichmüller M., Taylor G. H., Chandra D. and Teichmüller R. (1982) Textbook of Coal Petrology. Borntraeger, Stuttgart, 482 p.

Stanczyk K., and Boudou J.-P. (1994) Elimination of nitrogen from coal in pyrolysis and hydropyrolysis — a study of coal and model chars. Fuel 73, 940-944.

Stanczyk K., Dziembaj R., Piwowarska Z., and Witkowski S. (1995) Transformation of nitrogen structures in carbonization of model compounds determined by XPS. Carbon 33, 1383-1392.

Stiehl G., and Lehmann M. (1980) Isotopenvariationen des Stickstoffs humoser und bituminöser natürlicher organischer Substanzen. Geochim. Cosmochim. Acta 44, 1737-1746.

Straka P., Marinov S., and Tyuliev G. (2000) X-ray photoelectron spectroscopy of nitrogen and sulfur functionalities in organic substance of coal. Acta Montana B 10, 36-44.

Thorn K. A., and Mikita M. A. (1992) Ammonia fixation by humic substances: a nitrogen-15 and carbon-13 NMR study. Sci. Total Environ. 113, 67-87.

Tissot B., Durand B., Espitalié J., and Combaz A. (1974) Influence of nature and diagenesis of organic matter in formation of petroleum. AAPG Bull. 58, 499-506.

Townsend S. H., Abraham M. A., Huppert G. L., Klein M. T., and Paspek S. C. (1988) Solvent effects during reactions in supercritical water. Ind. Eng. Chem. Res. 27, 143149.

Vairavamurthy A., and Wang S. (2002) Organic nitrogen in geomacromolecules: Insights on speciation and transformation with K-edge XANES spectroscopy. Environ. Sci. Technol. 36, 3050-3056.

van Krevelen D. W. (1961) Coal. Elsevier, Amsterdam. 
van Zuilen M. A., Mathew K., Wopenka B., Lepland A., Marti K., and Arrhenius G. (2005) Nitrogen and argon isotopic signatures in graphite from the 3.8-Ga-old Isua Supracrustal Belt, Southern West Greenland. Geochim. Cosmochim. Acta 69, 12411252.

Verchovsky A. B., Watson J. S., Wright I. P., Lokhov K. I., Prasolov E. M., Prilepski E. B., Polekhovski Yu. S., and Goltsin N. A. (2006) Nitrogen isotopes in shungites. Geophys. Res. Abstracts. 8, 1607-7962.

Vidyadhar A., Rao K. H., and Chernyshova I. V. (2003) Mechanisms of amine-feldspar interaction in the absence and presence of alcohols studied by spectroscopic methods. Colloids Surf. A 214, 127-142.

Wang D., Lu X., Xu S., and Hu W. (2007) Comment on "Influence of a basic intrusion on the vitrinite reflectance and chemistry of the Springfield (No. 5) coal, Harrisburg, Illinois" by Stewart et al. (2005). Int. J. Coal Geol., 73, 196-199.

Ward C. R., Li Z., and Gurba L. W. (2005) Variations in coal maceral chemistry with rank advance in the German Creek and Moranbah Coal Measures of the Bowen Basin, Australia, using electron microprobe techniques. Int. J. Coal Geol. 63, 117-129.

Werner-Zwanziger U., Lis G., Mastalerz M., and Schimmelmann A. (2005) Thermal maturity of type II kerogen from the New Albany Shale assessed by ${ }^{13} \mathrm{C}$ CP/MAS NMR. Solid State Nucl. Magn. Reson. 27, 140-148.

Whiticar M. J. (1996) Stable isotope geochemistry of coals, humic kerogens and related natural gases. Int. J. Coal Geol. 32, 191-215.

Xiao B., Boudou J.-P., and Thomas K. M. (2005) Reactions of nitrogen and oxygen surface groups in nanoporous carbons under inert and reducing atmospheres. Langmuir 21, 3400-3409.

You C.-F., and Gieskes J. M. (2001) Hydrothermal alteration of hemi-pelagic sediments: experimental evaluation of geochemical processes in shallow subduction zones. Appl. Geochem. 16, 1055-1066.

$\mathrm{Yu}$ X. (2007) The preparation and characterization of cetyltrimethylammonium intercalated muscovite. Micropor. Mesopor. Mat. 98, 70-79.

Yuan P.-Q., Cheng Z.-M., Zhang X.-Y., and Yuan W.-K. (2006) Catalytic denitrogenation of hydrocarbons through partial oxidation in supercritical water. Fuel 85, 367-373.

Zhu Q., Money S. L., Russell A. E., and Thomas K. M. (1997) Determination of the fate of nitrogen functionality in carbonaceous materials during pyrolysis and combustion using X-ray absorption near edge structure spectroscopy. Langmuir 13, 2149-2157. 